\title{
Delegation and Motivation
}

Lukas Angst and Karol Jan Borowiecki

TEP Working Paper No. 1611

October 2011

Trinity Economics Papers

Department of Economics

Trinity College Dublin 


\title{
Delegation and Motivation
}

\author{
Lukas Angst \\ Department of Economics, University of Zurich \\ Karol Jan Borowiecki \\ Department of Economics, Trinity College Dublin
}

\begin{abstract}
$\underline{A B S T R A C T}$
In this article we study the determinants of decision rights transfer and its effects on the motivation of an agent. The study is based on a laboratory experiment conducted on 130 subjects playing an innovative principal-agent game. Interestingly, the results show that agents do not favour a delegation and a decision is considered rather burdensome. Although the experiment could not give support for the behavioural hypothesis of higher effort provided by participants who receive choice subsequently, the survey illuminates the interaction between delegation motives, effort motivators, goals and other perceptions of the agents.
\end{abstract}

Keywords: Organizational Behavior, Incentives, Experiments and Contracts

JEL Classifications: C92, D83, D23

This research is based on a revised version of Lukas Angst's Summa Cum Laude graded Master's thesis, supervised by Ernst Fehr and Holger Herz at the Department of Economics, University of Zurich. The authors acknowledge the outstanding academic advice and kind support offered by the supervisors and a generous research fund provided by the Department.

Corresponding Author: Karol Jan Borowiecki. Trinity College Dublin, Department of Economics, Dublin 2, Ireland. E-Mail: borowiek@tcd.ie. 


\section{Introduction}

The idea of fostering motivation of the employees through empowerment is well established in management theory. It brings up the question of centralized decision-making versus delegation. The typical focus has been on a trade-off between two effects coming along with delegation: on one hand, delegation leads to a better utilization of information distributed across the lower levels of the firm's hierarchy; on the other hand, it induces a loss of control for the upper-level managers. Despite the numerous implications identified in previous research, it is not entirely clear what role does motivation play. In particular, how is the motivation of an agent affected if he gets the decision rights assigned?

This study is based on a delegation experiment that was conducted in order to shed light on changes in the motivation of individuals who experience choice over some aspects of a task. In a laboratory setting motives and other effort promoting elements were explored. The idea of the experimental design was to investigate effects of delegation by sticking closely to the base principal-agent model provided by Aghion and Tirole (1997). The subjects have the task to screen among three projects and determine the best of them. To learn the profits of all possible projects, both parties have to decide for an effort which equates to the probability of becoming completely informed (referred to as Searchintensity). By setting the parameters in a manner that an agent is even worse off in case of delegation in terms of expected payoff, a higher Searchintensity must arise due to the delegation act itself.

Since there are no additional extrinsic incentives for the agents in case of delegation, a higher effort provided must be intrinsically motivated. Therefore, the benefits of the choice of the Searchintensity, as the central variable of this design, are twofold. ${ }^{2}$ First, as it measures the offered stake to find a good project it allows sheding light on the absolute extent of intrinsic motivation. Second, estimating the sources of motivation, in particular the way Searchintensity is affected by other variables like responsibil-

\footnotetext{
${ }^{2}$ Studies have employed two types of measures to assess intrinsic motivation: self-report and behavioural. Effort as a measure of motivation is frequently assessed as a self-report measure that asks participants the extent to which they want to exert effort on the target activity (e.g. Schraw, Flowerday, Reisetter, 1998). Behaviourally, effort can be measured as the number of trials attempted during an experimental phase or the number of mouse clicks on a computer during an experimental phase (e.g. Iyengar \& Lepper, 1999). Yet, in comparing the results of the two, it has been questioned if they can be considered alternate indexes of the same underlying construct. Whereas behavioural measures can have multiple determinants, selfreport measures may be subject to systematic reporting biases (Wicker et al., 1990).
} 
ity or beliefs, becomes possible. The results indicate that in this kind of setting the agents actually do not favour a delegation and a decision is considered rather burdensome. The study uncovers further interesting ways of interaction between delegation motives, effort motivators, goals and other perceptions of the agents.

The decision to transfer the decision rights is in accordance with the standard prediction applies. This proposition is also supported by the fact that $48 \%$ of the principals actually delegated. The findings further indicate that principals take primarily the giftbelief into account, whereas agents consider their own perceived friendliness to determine the desirabilities of both situations. The hypothesis of a higher average Searchintensity provided by the agents than by the principals must be rejected. Neither higher goal attainment nor significantly stronger feelings of responsibility can be detected. Agents prefer unambiguously to be subordinate, rather then make a costly and apparently demanding decision. Although they do not appreciate a delegation, they accept a potential delegation decision and set goals upon which they make their effort contingent. This is in accordance to Locke and Latham's (1990) goal-setting theory, which asserts that task performance is directly regulated by the conscious goals that individuals are going for on the task.

The goal attainment on its side depends mainly on the assumed delegation motives and on the responsibility perceptions of the agents. Other than among principals, where the felt responsibility neither affects effort nor goal attainment, responsibility considerations affect at least goal attainment amongst agents. The suggested delegation motives seem to be important for the agents in their decision process. They associate the delegation motive 'confidence in agent's effort' with positive feelings and cope with it by admitting responsibility, setting high goals and finally choosing a higher Searchintensity. With reference to the economic literature that assigns a signalling value to delegation, the positive character given to this delegation motive by the agents supports this valuation. The high rating of 'relief' and its correlation with the wish of centralization represents another interesting argument in the perception of a delegation, indicating that do not necessary favour a delegation and the necessity to take over decision is considered rather burdensome. Finally, the principals expect their agents to be more receptive for a delegation than they are in effect, and the agents in contrast assume their principals to associate friendlier intentions to their delegation decision than they actually do. Although the experiment could not give support for the behavioural hypothesis of higher 
effort provided by participants that receive choice subsequently, it gives interesting indication of how a delegation is perceived across individuals and the consequences these perceptions lead to.

The costs and benefits affecting the delegation decision have been widely studies. In analyzing the interaction between the two parties Dessein (2002) derives that under centralization the agent will always anticipate the discerning attitude of his principal and his information will be strategic towards the principal. Aghion and Tirole (1997) accordingly state that centralization may jeopardize communication between the agent and the principal when preferences are not sufficiently aligned. In reviewing capital allocation decisions Marino and Matsusaka (2005) found that under delegation the agent (assumed to be an empire builder) has room to overspend. Even when the principal keeps a hand in the decision, like it is assumed by Baker, Gibbons and Murphy (1999), the agent may distort his proposal to make the project look better than it is, resulting in an inefficiently large capital allocation and inefficient communication.

On the other hand, there are substantial arguments for positive impacts of delegation. Bénabou and Tirole (2003), argue that through a delegation the principal demonstrates her confidence in the agent's ability, and therefore higher efforts of the agent can be expected. The inherent signalling value of delegation is studied also by Swank and Visser (2006), who suggest that a principal can use delegation as a convincing communication device to signal his beliefs about the abilities of an agent. Bénabou and Tirole (2002) introduce a model which determines the valuation of self-confidence and demonstrate how it can influence the decision-making of individuals and eventually improve the welfare. Crémer (1995) argued that in principal-agent problems a credible commitment of a principal not to acquire information about the agent will strengthen his incentives for a positive result, overwhelming so the gains that could be made from better information acquired by the principal. Nonetheless, not only the contingent additional information must be considered in the delegation decision, but also the fact that the agent works on his own idea and may be more optimistic about the possibility of success (Zabojnik, 2002). A delegation again is the most credible commitment of the principal, and this sign of confidence might have even more positive consequences.

The remainder of this article is organized as follows. The next section describes the experimental design. The third section provides a discussion of the behavioural 
preditions. In the fourth section the empirical findings are presented and discussed, and in the last section, concluding remarks are provided.

\section{The experimental design}

The goal of the experiment conducted was to identify behavioural patterns and derive their motives and effort promoting elements arising from a delegation decision. At the same time the influence of extrinsic incentives had to be minimized in order to examine the pure effects of a delegation. Therefore, the experiment has been based on the princpal-agent model provided by Aghion and Tirole (1997). In the base version of the model the objective is to screen among three projects and determine the best of them. Project 0 is the outside option producing a minimum payoff for both the agent and the principal. Project 1 yields a higher payoff for the agent $\left(\pi_{\text {Agent, High }}>\pi_{\text {Principal, Low }}>0\right)$ and roject 2 a higher payoff for the principal $\left(\pi_{\text {Principal, High }}>\pi_{\text {Agent, Low }}>0\right)$. To learn the profits of all possible projects, both parties have to decide for an effort which equates to the probability of becoming completely informed (i.e. Searchintensity). The cost function of this Searchintensity is increasing and strictly convex. These characteristics secure that searching for information will always be profitable, but a probability of one will never be chosen. In the model of Aghion and Tirole the principal and the agent search simultaneously, and either he or she decides subsequently about the initiation of a project.

This article's underlying experiment represents the possible projects by thirty-five cards lying upside down. Only one card was turned up from the outset, representing the outside option. There were two good projects and an outside option. The outside option yielded for both parties the same payoff of $\pi_{\text {Agent, Outside }}=\pi_{\text {Agent, Outside }}=80$. Project 1 produced payoffs of $\pi_{\text {Agent, High }}=200$ and $\pi_{\text {Principal, Low }}=150$, and inversely project 2 yielded $\pi_{\text {Principal, High }}=200$ and $\pi_{\text {Agent, Low }}=150$. The costs of the search were about $\mathrm{c}(\mathrm{e})$ $=110 \mathrm{e}^{2}$, but with a steeper interval close to one and a flat interval close to zero in order to encourage choices between the two extrema. For the instructions and exact values see the Appendix 2. In the experiment a principal and an agent were teamed up to determine a project which yields a payoff for both individuals.

There have been applied two treatments: a centralization treatment and a delegation treatment. The centralization treatment is a one-sided search, where only the decisions of the principals affected the payoff for their teams. On a computer screen the 
principals were asked to choose a Searchintensity corresponding to the probability that all cards will turn up and they can choose their preferred project. Additionally, principals were asked to rate their goal determination. The agents contributed little in this treatment as they were only asked to estimate the Searchintensity chosen by their principals.

In the delegation treatment the principals were facing the decision between searching for a good project themselves and delegating this task to their respective agents. Similar to the centralization treatment, only one party had to search and decide for a project. Depending on the delegation decisions of the principals the search intensities had to be determined by them or by the agents. In either case the principals were additionally questioned about their goal attainment, beliefs, and gift and responsibility perceptions. The agents were also asked to determine their search intensities before knowing the actual delegation decisions of their principals. Additionally, the agents were asked about their promoters of effort, sense of responsibility, assumed delegation motives, gift perception, goal attainment and search intensity estimations. All variables are summarized in Appendix 1.

The principal-agent game was played by a total of 130 subjects divided into four sessions. In each session the participants played one round in the delegation treatment and one round in the centralization treatment. The payoff of the first period was not shown until the second period was through. Sessions 1 to 3 started with the centralization treatment, followed by a period of the delegation treatment. Session 4 observed an inverse order. Upon arrival subjects were randomly allocated a role as principal or as agent and kept this role during the whole experiment, whereas the pairs of principals and agents were reassigned between the treatments. All experiments were computerized using the software 'z-Tree' (Fischbacher, 2007) to run the experiment. Session 1 was framed on responsibility, meaning that the instructions used terms like "bearing responsibility" or "shifting responsibility" instead of terms like "transferring decision rights", like they were used in sessions 2 to 4 . The latter three sessions were framed in a neutral manner, without terms like 'trust' or 'expectation', and in all four sessions the subjects were called 'participant A' and 'participant B'.

The participants were mostly Swiss students from from the University of Zurich and the Swiss Federal Institute of Technology in Zurich with an average age of 22.7 
years. The game was played in German and the earnings per participant averaged on 32 Swiss francs ( $\$ 32.00$ at the time of the experiment).

\section{Behavioural Predictions}

The behavioural predictions are depending on the assumptions about the preferences of the participants. For both treatments the decisions for a rational and risk-neutral participant, according to the standard theory, should be derived at first, in order to subsequently prognosticate other possible outcomes. In the centralisation treatment, since the possible payoffs and the costs are known, a rational principal could set up the following equation to maximize her expected utility (EU) dependent on the searchintesity (s):

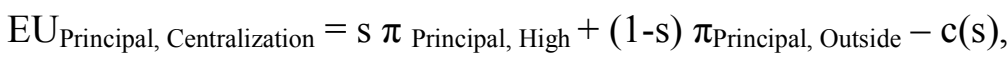

yields the first order condition:

$\mathrm{dEU}_{\text {Principal, Centratlization }} / \mathrm{ds}: \pi_{\text {Principal, High }}-\pi_{\text {Principal, Outside }}=\mathrm{c}^{\prime}(\mathrm{s})$

Pluging in of the actual values results in an optimal Searchintensity of $\mathrm{s}^{*}=0.55$ (since only values in a 0.05 interval could be chosen), as can be viewed in Figure 1. A rational and risk-neutral participant, who should always choose a Searchintensity of s* to maximize her expected utility, has an expected utility equal to $E U_{\text {Principal, }}$ Centralization $=112.5$. Taking additionally into account that individuals act risk-averse in an experimental setting (see e.g. Rabin, 2000), and prosocial considerations may be of influence as well, one could expect a slightly higher searchintesity on average.

In the delegation treatment, the principal transfers the decision rights to her agent and therefore the final payoff depends on the effort provided by the agent. Subsequent to a delegation, the principal's payoff is either $\pi^{0}$, in case of an unsuccessful search, or $\pi^{\mathrm{L}}$, in case of a successful search. Depending on the search effort she expects her agent to contribute, she will delegate the task. If she estimates her agent to be rational and risk-neutral, she will expect him to choose a Searchintensity of $\mathrm{s}^{*}=0.55$. This would yield an expected utility of $\mathrm{EU}_{\text {Principal, Delegation }}=118.5$, which is greater than the expected utility in the centralization treatment. As can be seen from Figure 2, for an expected 
Searchintensity higher than 0.45 the task should always be delegated. If the principal estimates her agent to be risk averse, she can expect an even higher payoff by delegating. In either case a delegation induces a loss of control but also a higher expected payoff for the principal. In the delegation treatment one could expect a higher effort by the non-delegating principals, because they might perceive additional responsibility when they have the possibility of delegation and do not choose it.

Aghion and Tirole (1997) predict delegation in circumstances where the principal can trust the agent. This is the case when the outcome is important to the agent, either because his possible private benefits are high or because the agent fears the principal's choice and thus needs sufficient information to convince her of his choice. Yet, in this design with one-sided search and symmetric conditions the points made by Aghion and Tirole can not be directly applied. Although there is a considerable difference in payoffs between the three projects, the costs of choice are evident, and since there will be no further interaction after the delegation decision, reputation considerations can be excluded.

In the delegation treatment the agent's decision is the same as the principal was facing in the centralization treatment and accordingly has the same standard prediction. Although an agent is worse off in case of delegation, in light of behavioural theories and experimental evidence one could expect a higher average Searchintensity chosen by the agents. Since the span of control, the complexity of the task und the degree of relatedness are the same for the agent as they are for the principal, a possible higher motivation and effort of the agent must arise out of the delegation act itself.

\section{Empirical Results}

\subsection{Search Intensity}

\section{Choice of Search Intensity}

Figure 3 illustrates the search intensities chosen by the principals, who hold the decision rights from the outset of the experiment, with their respective densities in the the centralization treatment. The average Searchintensity of the principal in the centralization treatment is avgSP_Centr $=0.51$ and has a standard deviation (sd) of 22.27. Compared to the standard prediction of an average Searchintensity equating to 0.55 , this result cor- 
responds fairly well with the behavioural prediction. Yet, the argument of risk aversion has to be ignored, and it appears that the principals were ready to gamble. The goal attainment shows an average rating of avgGoal_Centr $=4.6(\mathrm{sd}: 1.47)$, and significantly correlates with the Searchintensity (OLS-Coefficient: 6.56; $>>0.002$ ). The agents expected an average of Searchintensity of the principal avgBA_Centr $=52.3$ (sd: 19.57), which corresponds quite exactly to the actual data. In the delegation treatment twenty six of the principals (i.e. 52\%) kept the decision right and chose an average Searchintensity of avgSP_Del $=50$ (sd: 20.69). Figure 4 shows the search intensities with their respective densities chosen by the non-delegating principals. Those principals additionally had to rate their felt responsibility for the payoff of their agents. Although one would expect correlation of this variable with the provided effort, its coefficient, as presented in Table 1, is insignificant. On the other hand, non-delegating principals set high goal attainment, and the according OLS coefficient shows significant correlation with the search intensities, even though not as strong as in the centralization treatment. Feelings of responsibility do not seem to determine the Searchintensity of the principals who keep the decision right. It is interesting to observe that non-delegating principals set high goals which they want to reach by choosing an acording seachintensity. The search intensities for the delegation case of all fifty agents are depicted in Figure 5. Out of these search intensities, which potentially would be decisive, results an average search intensity of $\operatorname{avgSA} \mathrm{Del}=52.1$ ( $\mathrm{se}:$ 18.13). The average effort provided by the agents is only marginally higher then the one provided by the principals in the centralization treatment.

The agents' goal attainment in case of delegation is on the same level as it is for the principals. The OLS point estimate as summarized in Table 2 indicates a significant correlation with the Searchintensity. The validity of goal as a predictor of the effort is about the same as it is for the principals in the centralization treatment. As for the principals, the perceived responsibility for the payoff of the respective counterparty has no direct effect on the determination of the Searchintensity. Furthermore, the agents' perceived responsibility correlates significantly with goal attainment (OLS-Coefficient: $0.29 ; \mathrm{p}>0.003$ ), whereas this correlation can not be detected amongst principals (OLSCoefficient: $0.10 ; p>0.470)$. A regression of the searchintesity on the agent's assumption about the expectation of the principals (BA_Secorder) and the agent's belief about the chosen searchintensitiy in case of no delegation $\left(B A \_N o D e l\right)$ produces another inter- 
esting result. The variable $B A \_N o D e l$ has ceteris paribus strong correlation with the effort provided by the agent, while $B A \_$Secorder does not have a significant coefficient in this model. Although the two beliefs may relate strongly to each other, this leads to the statement that the agents' main intention is not to fulfil the principals' expectation, but rather to provide as much as they assume their principals would have contributed. Putting themselves in the principal's position seems to be substantial to the agents.

\section{Comparison of Search Intensities}

To clarify if there really is no significant difference in the effort provided across treatments and roles, as it seems at a first glance, the three effort decisions are examined here. The comparison is based on the results from the chosen Searchintensity by the principals in the centralization treatment, the agents in the delegation treatment and the non-delegating principals in the delegation treatment.

The comparison of the principal's Searchintensity in the centralization treatment and the agent's Searchintensity in the delegation treatment is conducted by the means of a simple OLS model. The dependent variable is the chosen Searchintensity by the subject. The variable of main interest is the introduced dummy variable Principal that takes the value one for principals and zero for agents. A possible significant negative coefficient of the Principal, indicating higher search efforts provided by the agents due to the transfer of decision rights, would give support for the behavioural hypothesis. In order to control for differences in the provided effort by the subject, the specification contains further a measure for goal attainment (Goal). The results are presented in Table 3 and indicate an insignificant coefficient of the Principal variable. This finding does not support the expected higher effort provided by the agents. An analogous model can be estimated solely for the delegation treatment. A regression of the search intensities provided in the delegation treatment, based on 26 observations of principals and 50 of agents, delivers the point estimates as summarized in Table 4. The dummy-variable Principal takes now the expected negative value. It lies however outside the usual confidence interval suggesting a rejection of the behavioural hypothesis.

Finally, a comparison of the principals' Searchintensity in the centralization treatment and in the delegation treatment if the deicision rights have not been transferred, is conducted. Although the principals faced the same decision about the search 
intensities in the delegation treatment as in the centralization treatment, the additional possibility of delegation may nevertheless have implications on their chosen effort. To infer the presence of such difference, a dummy-variable Treatment, that takes the value one for delegation treatment and zero otherwise, is integrated into the regression. The estimation, as can be viewed in Table 5, delivers an insignificant coefficient of the dummy-variable. The option of delegation does not seem to affect the non-delegating principals in their effort decision.

\subsection{Principals' delegation decisions}

The principals' decisions to delegate are analyzed by using the logit-model and subsequently computing the marginal effects. The resulting coefficients indicate the marginal change of the possibility of a delegation followed by a marginal increase of the exogenous variable around the average. The tests show that besides the desirabilities of centralization or delegation, as could be expected, only the belief of the principal about the perceived friendliness of a delegation by his agent (Giftbelief) has a significant correlation with the delegation decision of the principals. The resulting correlation between the delegation decision and the rating of Giftbelief is negative and amounts to $13.12 \%$ (zvalue: -2.36; $\mathrm{P}>|\mathrm{z}|$ : 0.018). One would rather expect a positive correlation between delegation and the belief of the agent's positive receptiveness, because if the agent appreciates a delegation then he might reciprocate. Anyhow, this is a first sign that the principals do not delegate out of friendliness.

To further describe the two groups of principals and their attitudes, the means of the other variables, divided into delegating and non-delegating principals, are graphically presented in Figure 6. It is interesting to observe that the perceived friendliness of a delegation decision (Gift) and Giftbelief are both higher amongst non-delegating principals. If those variables are interpreted as a measure of friendliness of delegation, the emerging picture could indicate that the principals do not delegate because they perceive it as friendly. The desirabilities of the two situations correspond very well with the actual decisions: principals who value authority, do not transfer the decision rights, whereas subjects who value delegation, hand over the power. The high values for goal attainment indicate that a positive outcome is crucial to the principals and that this does not prevent from delegating. Interestingly, the high values are not explained by the fact 
that delegating principals with high goal attainment expect their agents to choose a high Searchintensity. Logit regression does not assign significant coefficients to this belief $\left(B P_{-} D e l\right)$ and additionally the mean belief of the delegating principals is only avgBP_Del $=50.42$ (se: 17.69). So the delegating principals expect about the same effort of their agents as they would have chosen themselves and therefore this explanation must be rejected. A strong motive could be relief of the task or true rationality as proposed by the standard theory.

\subsection{Agent Decisions}

In this section the decisions of the agents will be analyzed. In the following the perceptions of the agents, the effort promoting variables, and their intercorrelations are presented in order to interpret them subsequently.

Figure 7 depicts the agents' desirabilities of delegation or centralization, their perceived friendliness of a delegation (Gift) and the friendliness perceived by a delegating principal (Giftbelief). It is interesting to observe that agents rate a centralized situation higher than a situation in which they have to decide for a Searchintensity. To assess if there is a connection between gift perceptions and desirabilities of the two situations, a regression of the two perceptions on the desirability has been estimated. The desirability of centralization is modelled in Table 6 and the desirability of delegation in Table 7. The point estimates indicate that the friendlier the agents perceive a delegation (Gift), the higher is the desirability of delegation and the lower is the desirability of centralization. Yet, the effect of Gift on the desirability of delegation is much stronger then the effect on the desirability of centralization. The belief about the principal's friendliness perception (Giftbelief) does not affect the desirability of either situation. To further analyze the agent's perception of a delegation, based on eight motives assummarized in the Appendix 1, the potential delegation motives are assessed. By computing all the single correlations between the delegation motives and the provided effort, only the motive Confidence in agent's effort showed a significant correlation with the chosen Searchintensity (OLS-Coefficient: 3.83; $\mathrm{p}>0.049$ ). To control for motives with the same or similar valence, their intercorrelations are computed and presented in Table 8. 
There seem to be three different characters of motives that represent the view of the agents quite well. First, the highest rated delegation motive (Relief), allows hypothesizing that the agents perceive the task as demanding. Additionally, a single correlation with the desirablity of centralization (OLS-Coefficient: $0.353 ; p>0.061$ ) could lead to the conclusion that agents do not favour a delegation. Remarkably, the motive Relief has a significantly single correlation with goal attainment (OLS-Coefficient: 0.355 ; $>$ 0.018), while showing no connection to the felt responsibility for the payoff of the principals (OLS-Coefficient: $0.039 ; \mathrm{p}>0.859$ ). So a delegation due to relief considerations leads to higher goal attainment but does not affect the perceived responsibility. Second, there is a group of motives around Confidence in agent's effort that generally have a positive imprint and show high coherence. Jointly, they explain a large part of the agent's responsibility perception $\left(R^{2}=0.36\right)$. Third, there is an important group that presumes delegation motives with a clearly negative imprint. The motives Calculation and Selfishness have a strong positive intercorrelation and are rated very high. Besides, they have no correlation with responsibility perceptions or goal attainment. This leads to the insight, that most agents did not favour a delegation. It can be concluded, with a look at the rankings of the motives and the desirabilities of both situations, that the agents assess a delegation as rather negative. Nevertheless differences in the perceptions that presumably lead to different outcomes, can be identified.

Next, the analysis is directed at the effort motivators. To assess the motives, the agents rating of the motives are analysed (see Apendix 1 for details). The four motives,as depicted in Table 9, show high intercorrelations. Additionally, the motivators explain quite well both responsibility perceptions $\left(\mathrm{R}^{2}=0.3525\right)$ and goal attainment $\left(\mathrm{R}^{2}\right.$ $=0.4666$ ). Table 10 summarizes the point estimates. Altough not significant, the sign of the coefficient of Cope with obligation in the regression with responsibility surprises here. Obviously, obligation and responsibility are perceived differently. The willingness to use the given opportunity is positively related to responsibility perceptions, although this motivator was formulated rather self-serving. In order to identify agents that were highly motivated through a delegation, they were asked to self assess a particular motivation by yes or no. Seven out of fifty answered yes and specified the deciding motivators as illustrated in Figure 8. Obviously there are both prosocial (responsibility and obligation) and self-serving (use opportunity) considerations that motivate for the provision of a high Searchintensity. By reviewing single correlations between the motivators and the Searchintensity, only the motivator Cope with responsibility has a direct effect 
on the chosen Searchintensity that is significant on $2 \%$ significance level. On the $6 \%$ significance level the motivator Cope with obligation has a direct correlation with the Searchintensity as well. The other two have no direct effect, but affect the responsibility perception and goal attainment. Figure 9 outlines the most significant single correlations among the main motivators, responsibility and goal attainment of agents. To simplify the picture only the strongest correlations are drawn here. The numbers represent the single correlation coefficient estimates, and the stars declare the levels of significance. As described before, there seem to be three different characters of delegation motives assessed by the agents. While the delegation motive Confidence in agent's effort by itself has significant correlation with both the perceived responsibility and goal attainment, the delegation motive Relief is only correlated with goal attainment (OLSCoefficient: $0.355 ; \mathrm{p}>0.018$ ). The fact that the delegation motive Relief has no single correlation with neither of the proposed motivators allows hypothesizing that an important motivator was left out in the design. Relief positively correlates with the desirability of centralization (OLS-Coefficient: $0.353 ; \mathrm{p}>0.061$ ), but at the same time raises the goal attainment in case of delegation. This is an interesting finding, because high goal attainment is undoubtedly connected to high provided effort. Thus, although not favourable, a delegation out of relief considerations brings the agents to raise their goal attainment and thereby to contribute more.

The motive Confidence in agent's effort has strong significant single correlation with the three goal-determing motivators, especially Cope with responsibility and obligation, but Use opportunity as well. Although it was not rated as one of the top motives, it is therefore a very meaningful delegation motive. It moreover significantly correlates with three other delegation motives that have a positive imprint. This group of delegation motives and its inherent sign of trust cause the agent to feel responsible or even obliged to choose a high Searchintensity. At the same time the agents want not only to cope with the responsibility, but to use the opportunity to realise a beneficial project.

Finally, the third and jointly highest rated type of delegation motives with a more negative character is represented by Calculation and Selfishness. They have no or a negative correlation with the perceived responsibility (or the corresponding motivators Cope with responsibility and respectively Cope with obligation). The most negatively embossed delegation motive Selfishness shows no correlation with any interesting variable (except a negative one to Gift and Desirability of delegation), whereas the associ- 
ated delegation motive Calculation has a positive single correlation with the motivator Use opportunity (OLS-Coefficient: 0.374; $\mathrm{p}>0.09$ ). For illustration purposes the most significant single correlations are summarized in Figure 10.

\subsection{Framing Responsibility}

Since Session 1 was framed differently, the data of this session can not be interpreted jointly with the data of the other sessions. Nevertheless, since the session was framed on responsibility, the results allow sheding light on the importance of responsibility when delegation issues are concerned. In the instructions to Session 1 delegation was not termed as "transfer of decision rights", but as "transfer of responsibility". Furthermore, the instructions used the term "person that bears the responsibility" rather than "decision maker". Table 11 presents summary statistic on the main variables for the Session 1 and the remaining sessions. The results show that the conducted framing does not significantly affect the choices of the participants.

The framing had no effect on the perceived responsibility of the participants. A possible explanation may be given by the experimental research done by Sieck and Yates (1997), who examined the consequences of exposition on framing effects. Exposition means that participants had to write down their reasons for a certain choice and thereby heighten their level of processing of the problem. Through their experiment they identified a choice effect and a confidence effect of exposition. For the choice effect, exposition reduced the influence of alternative frames. The confidence effect strengthened the subjects' beliefs of making the best choice, corresponding to confidence of choice.

Since the instructions of the underlying experiment were very thorough and the participants, after reading them, had to solve five examples in order to begin the game, it can be assumed that there was a high grade of exposition, and therefore, framing had little effect. 


\subsection{Impatience in a Reversed Order Setting}

The Session 4 was played in reverse order, i.e. the centralization treatment was played first, followed by the delegation treatment. The possible impatience by the agents in waiting for their first actual decision, as it can be observed often in real life work settings, may be an important driver for variation in the results. The means of the main variables are summarized in Table 12. The emerging picture indicates clear distinctions in the chosen search intensities between principals and agents. The stronger desire for delegation amongst principals and the generally higher rated gift perceptions are additional signs of preference for a transfer of decision rights.

The higher level of search intensities correlates significantly with the strong goal attainment amongst agents (OLS-Coefficient: 9.8; $\mathrm{p}>0.000)$, which in turn correlates most strongly with the motivator of using the given opportunity (OLS-Coefficient: 0.49; $p>0.003$ ). To emphasize the significant difference in the effort provided by agents and principals of this session, the Searchintensity solely for the Session 4 is modelled. The results are presented in Table 13. The comparison of the principals' search intensity in the centralization treatment and the agents' search intensity in delegation treatment shows that the role significantly correlates with the effort provided. This gives support for the behavioural hypothesis. Nonetheless, the small number of observations (i.e. 16 principals and 16 agents) does not allow a general statement and therefore further analysis will be left out here.

\section{Discussion}

The experimental design used here may not be the best way to control for an increase in effort as a result of heightened intrinsic motivation due to the provision of choice. Since the Searchintensity simultaneously serves as probability, it can not be solely interpreted as effort. As Langer (1975) has argued, providing choice in tasks where outcomes are chance-determined leads to inappropriately heightened expectations of success. This may lead to low stake provided by agents. In many contexts it has been shown that those who enjoy choice about a task, or about the features of a task, will perceive themselves as doing better. This describes a causal path from choice through motivation and actual performance to perceived performance (Tafarodi et al.: Confidence of choice, 
p.1407, 1999). Overconfidence in this game could well lead to a lower search intensity. The results of Tafarodi et al. (1999) corroborate the assumption that choice enhances perceptions of competence independent of actual performance, whereas a boost in perceived competence does little to enhance performance but still has an intrinsic value. The heightened expectations and enhanced perception of performance could be causes of the low search intensity level among agents. These effects might work in the opposite direction than the proposed motivational impact in this chance game. Anyhow, the eventual effect of delegation on the self-confidence of the agents could not be assessed in this design.

Another possible reason for the low level of search intensities could be due to the fact that the strategy method was applied. A hypothetical delegation may not have the same impact on the agents as a real delegation. Additionally, in three out of four sessions the delegation treatment was played first. During this first period the agents were not aware of the fact that in case of no delegation they would have no influence during the rest of the experiment. On the other hand, in session four, with reversed order of periods, the agents already participated in a round with no decision. Due to intensed will and impatientness for exerting influence, they may have chosen higher search intensities in period four. Or in terms of psychologists, the reason for increasing effort by the agents in session four may be to raise the chance of a behaviour-result contingency (Heckhausen, 2006), followed by higher will for effectiveness. Yet, the possible grade of experiencing competence or effectiveness is hard to determine. Studies found that controlling conditions led to better performance on trivial tasks (Grolnick \& Ryan, 1987; McGraw, 1978) and that when a job involved only mundane tasks, there appeared to be no performance advantage of autonomous motivation. But even in this kind of jobs, autonomous motivation will bring greater job satisfaction and well-being (Ilardi et al., 1993; Shirom et al., 1999). The studies suggest that autonomous motivation is superior in situations that include both complex tasks that are interesting and less complex tasks that require discipline. How complex this actual task here is perceived was unfortunately not assessed and therefore no statement can be made.

With reference to the self-regulatory perspective, proposed by Baumeister and colleagues (Muraven \& Baumeister, 2000; Muraven et al., 1998), that initially was to be omitted, additional inference can be made. Their theory suggests that choice may have disadvantages, as all acts of choice or self-control are effortful and draw on a limited 
resource that can be depleted, analogous to a source of energy or strength. Regarding the experimental design here, this theory could have relevance. As the agents consider the delegation motive Relief as most important and do not favour a delegation, they may experience the choice of search intensity as exhausting. Accordingly, it was found that choice becomes overwhelming and demotivating when there is a large number of options (Iyengar \& Lepper, 2000; Schwartz, 2000). For deciding agents there are twentyone options to choose from, each one connected to a different chance, cost and expected outcome. This may seem too exertive for the agents in a laboratory setting and hence not enjoyable. Consequently, according to the self-regulatory theory, it may be these 'easy' choices that will result in the least ego-depletion and allow for more positive effects of being given a choice. Conversely, in line with SDT, the more options given, the more pronounced the perception of having experienced choice. Again, the determination of a costly probability may raise autonomy perceptions, but in order to experience effectiveness (or competence) it may not be a promising choice. Autonomy as the enabling frame to feel competence could be too costly here (in terms of responsibility, monetary payoff, stress), and prevail over the positive experience. To test the depleting effect of the actual decision here, one could enhance or diminish the choice by adding or reducing options through offering larger or smaller intervals of searchintesities. Regarding this, a recent meta-analysis (Patall et al., 2008) found that a setting with two to four successive choices in a single experiment has the largest positive effect of choice on intrinsic motivation. This applies even when these choices are instructionally irrelevant, i.e. choices which are not highly meaningful. Analogously, such experiment could be expanded by allowing choices about e.g. the screen colour or font type.

Referring to the self determination theory, that intrinsically motivated behaviour is based in people's needs to feel competent and self-determined, the numerous interdependences of the various variables in the design make it hard to identify, if a participant perceived autonomy and feelings of competence through the delegation of the task. Since challenge, which serves for examination and preservation of the feelings of competence, arises out of the comparison between demand and ability (Heckhausen, 1963) it will vary across individuals. Obviously a delegation involving risk and no clear advantage for the agent leads to variable interpretations by him, whereas the most persistent affect motivation and effort. In order to point out the predominant interpretation, in future experiments contributing to the research on this topic the agents should be given distinctive ways to react. 
In reference to the participation view of delegation (Aghion \& Tirole, 1997) and the consumption value of high self-confidence (Bénabou \& Tirole, 2003), which assigns a higher utility to a recipient of decision rights, no statement can be made either. An actual positive impact on an individual's utility through higher belief in his abilities cannot be assessed in this design. Nevertheless, a signalling value can be recognized, if one looks at the assumed delegation motives and their implications. The fact that both principals and agents put themselves in position of their counterparties to assess their own perceptions and come to a decision, speaks for a high influence of the counterparties character on the signalling value. In a real life work setting one can imagine that a delegation by a well respected superior has a much stronger inherent value for the agent than the same act of a line manager. This can be seen in accordance with the construct of relatedness of the self determination theory as well. To approximate real-life work situations, controlled forms of relatedness should be integrated into future experimental designs. Yet, relatedness was excluded in the present design, and therefore no additional evidence can be adduced.

\section{Conclusion}

Although the hypothesis of a higher provided stake in case of delegation must be rejected, some means which seem to result in motivation could be identified. Apparently, agents affiliate multiple conceptions to a delegation that is not clearly advantageous to them. The key of understanding in this kind of setting seems to be the fact that the judgement of a decision is done by putting oneself in the counterparty's position. So if a principal can plausibly convey her motives to her agent, she can very well change his beliefs and perceptions. This complies with the signalling value of delegation identified by several scholars (e.g. Bénabou \& Tirole, 2003). Yet, this value can eventually have positive or negative implications for the provided effort. So a delegation due to e.g. relief considerations leads to higher goal attainment but does not affect the perceived responsibility.

The aim of excluding reciprocation has been met and thereby numerous different implications of delegation could be found. Furthermore, several indications for future research could be given. In order to clear out the conception, the most persistent effects of a delegation on the goal attainment, the challenge or burden of the task and the level 
of confidence should be clarified in future studies. They appear to be the most crucial factors in measuring additional motivation arising out of a delegation. 


\section{References}

Aghion P. \& Tirole J. (1997): Formal and Real Authority in Organizations. Journal of Political Economy 105 (1) 1-29.

Baker G., Gibbons R. P., Murphy K. J. (1999): Informal Authority in Organizations. Journal of Law, Economics, and Organization 15, 56-73.

Bénabou R. \& Tirole J. (2002): Self-confidence and personal motivation. Quarterly Journal of Economics 117 (3) 871-915.

Bénabou R. \& Tirole J. (2003): Intrinsic and Extrinsic Motivation. Review of Economic Studies 70 (3) 489-520.

Bénabou R. \& Tirole J. (2003): Intrinsic and Extrinsic Motivation. Review of Economic Studies 70, 489-520.

Crémer J. (1995): Arm's Length Relationships. The Quarterly Journal of Economics 110 (2) 275-295.

Fehr E \& Schmidt K. M. (2000): Theories of Fairness and Reciprocity Evidence and Economic Applications. CEPR Discussion Paper No. 2703.

Fischbacher U. (2007): A Toolbox for Readymade Economic Experiments. Experimental Economics 10 (2) 171-178.

Heckhausen J. (2006): Motivation und Handeln. Heidelberg SpringerVerlag.

Heckhausen H. (1963): Hoffnung und Furcht in der Leistungsmotivation. Meisenheim/Glan Hain.

Ilardi B. C., Leone D., Kasser T., Ryan R. M. (1993): Employee and supervisor ratings of motivation: main effects and discrepancies associated with job satisfaction and adjustment in a factory setting. Journal of Applied Social Psychology 23, 1789-1805.

Iyengar S. S. \& Lepper M. R. (1999): Rethinking the value of choice: A cultural perspective on intrinsic motivation. Journal of Personality and Social Psychology 76, 349-366.

Langer E. J. (1975): The Illusion of Control. Journal of Personality and Social Psychology 32 (2) 311-328.

Locke E. A. \& Latham G. P. (1990): A theory of goal setting and task performance. Englewood Cliffs. NJ Prentice-Hall. 
Marino A. M. \& Matsusaka J. G. (2005): Decision Processes, Agency Problems, and Information: An Economic Analysis of Capital Budgeting Procedures. Review of Financial Studies 18 (1) 301-325.

McGraw K. O. (1978): The detrimental effects of reward on performance: A literature review and a prediction model. In Lepper M. R. \& Greene D. (Eds.): The hidden costs of reward (pp. 33-60). Hillsdale. NJ: Erlbaum.

Muraven M. \& Baumeister R. F. (2000): Self-regulation and depletion of limited resources: Does self-control resemble a muscle? Psychological Bulletin 126 (2) 247-259.

Muraven M., Baumeister R. F., Tice D. M. (1998): Self-control as limited resource: Regulatory depletion patterns. Journal of Personality and Social Psychology 74 (3) 774-789.

Patall E. A., Cooper H., Robinson J. C. (2008): The Effects of Choice on Intrinsic Motivation and Related Outcomes: A Meta-Analysis of Research Findings. Psychological Bulletin 134 (2) 270-300.

Rabin M. (2000): Risk aversion and expected-utility theory: A calibration theorem. Econometrica 68 (5) 1281-1292.

Ryan R. M. \& Grolnick W. S. (1987): Origins and pawns in the classroom: Self-report and projective assessments of individual differences in children's perceptions. Journal of Personality and Social Psychology 5 (2) 550-558.

Schraw G., Flowerday T., Reisetter M. F. (1998): The role of choice in reader engagement. Journal of Educational Psychology 90, 705714.

Schwartz B. (2000): Self-determination: The tyranny of freedom. American Psychologist 55 (1) 79-88.

Shirom A., Westman M., Melamed S. (1999): The effects of pay systems on blue-collar employees' emotional distress: The mediating effects of objective and subjective work monotony. Human Relations 52 (8) 1077-1097.

Sieck W. \& Yates J. F. (1997): Exposition Effects on Decision Making: Choice and Confidence in Choice. Organizational Behavior and Human Decision Processes 70 (3) 207-219.

Swank O. H. \& Visser B. (2006): Motivating Through Delegating Tasks or Giving Attention. Journal of Law, Economics and Organization 23 (3) $731-742$.

Tafarido R. W., Milne A. B., Smith A. J. (1999): The Confidence of Choice: Evidence for an Augmentation Effect on Self-Perceived 
Performance. Personality and Social Psychology Bulletin 25 (11) 1405-1416.

Tirole J. (2002): Rational irrationality: Some economics of selfmanagement. European Economic Review 46, 633-655.

Wicker F. W., Brown G., Paredes V. (1990): Competing activities and measures of intrinsic motivation. Journal of Social Psychology 130, 813-819.

Zabojnik J. (2002): Centralized and Decentralized Decision Making in Organizations. Journal of Labor Economics 20 (1) 1-22. 


\section{Tables}

Table 1. Non-delegating principal's searchintensity.

\begin{tabular}{l|l|lll}
\hline Exog. Variable & Mean (rsd) & $\begin{array}{l}\text { Coefficient } \\
\text { (rse) }\end{array}$ & t-value & $\mathrm{P}>|\mathrm{t}|$ \\
\hline Goal_NoDel & $4.77(1.45)$ & $5.978(2.82)$ & 2.12 & 0.044 \\
Resp_NoDel & $2.88(2.1)$ & $0.925(1.7)$ & 0.5 & 0.591 \\
\hline
\end{tabular}

Note: Robust standard deviation (rsd) and robust standard errors (rse) are reported in parentheses.

Table 2. Agents' searchintensities.

\begin{tabular}{l|l|lll}
\hline Exog. Variable & Mean (sd) & $\begin{array}{l}\text { Coefficient } \\
\text { (rse) }\end{array}$ & t-value & $\mathrm{P}>|\mathrm{t}|$ \\
\hline Goal & $4.74(1.12)$ & $6.5(2.16)$ & 3.00 & 0.004 \\
Responsibility & $2.16(1.6)$ & $0.47(1.65)$ & 0.34 & 0.736 \\
BA_Secorder & $51.7(17.7)$ & $0.001(0.20)$ & 0.01 & 0.996 \\
BA_NoDel & $50.7(16.4)$ & $0.845(0.22)$ & 3.94 & 0.000 \\
\hline
\end{tabular}

Note: See Table 1.

Table 3. Role influence on the searchintensity (1).

\begin{tabular}{l|lll}
\hline Exog. Variable & $\begin{array}{l}\text { Coefficient } \\
\text { (rse) }\end{array}$ & t-value & $\mathrm{P}>|\mathrm{t}|$ \\
\hline Goal & $6.636(1.45)$ & 4.57 & 0.000 \\
Principal & $0.329(3.72)$ & 0.09 & 0.930 \\
\hline
\end{tabular}

Note: Robust standard errors (rse) are reported in parentheses.

Table 4. Role influence on the searchintensity (2).

\begin{tabular}{l|lll}
\hline Exog. Variable & $\begin{array}{l}\text { Coefficient } \\
\text { (rse) }\end{array}$ & t-value & $\mathrm{P}>|\mathrm{t}|$ \\
\hline Goal & $6.671(1.73)$ & 3.85 & 0.000 \\
Principal & $-3.814(4.35)$ & -0.88 & 0.384 \\
\hline
\end{tabular}

Note: See Table 3. 
Table 5. Treatment influence on principals' searchintensity.

\begin{tabular}{l|lll}
\hline Exog. Variable & $\begin{array}{l}\text { Coefficient } \\
\text { (rse) }\end{array}$ & t-value & $\mathrm{P}>|\mathrm{t}|$ \\
\hline Goal & $6.431(1.9)$ & 3.37 & 0.001 \\
Treatment & $-2.588(3.6)$ & -0.72 & 0.476 \\
\hline
\end{tabular}

Note: See Table 3.

Table 6. Agent's desirability of centralization.

\begin{tabular}{l|lll}
\hline Exog. Variable & $\begin{array}{l}\text { Coefficient } \\
\text { (rse) }\end{array}$ & t-value & $\mathrm{P}>|\mathrm{t}|$ \\
\hline Gift & $-0.34(0.18)$ & -1.91 & 0.062 \\
Giftbelief & $-0.02(0.13)$ & -0.15 & 0.884 \\
\hline
\end{tabular}

Note: See Table 3.

Table 7. Agent's desirability of delegation.

\begin{tabular}{l|lll}
\hline Exog. Variable & $\begin{array}{l}\text { Coefficient } \\
\text { (rse) }\end{array}$ & t-value & $\mathrm{P}>|\mathrm{t}|$ \\
\hline Gift & $6.23(0.13)$ & 4.87 & 0.000 \\
Giftbelief & $0.01(0.11)$ & 0.06 & 0.955 \\
\hline
\end{tabular}

Note: See Table 3. 
Table 8. Means, standard deviations and correlations of the delegation motives.

\begin{tabular}{|c|c|c|c|c|c|c|c|c|c|c|}
\hline & Mean & S.D. & 1 & 2 & 3 & 4 & 5 & 6 & 7 & 8 \\
\hline Relief & 3.86 & 1.050 & 1 & & & & & & & \\
\hline Calculation & 3.70 & 1.111 & -0.051 & 1 & & & & & & \\
\hline $\begin{array}{l}\text { Selfishness } \\
\text { Conf. in A- }\end{array}$ & 3.14 & 1.178 & 0.059 & $0.56^{* * *}$ & 1 & & & & & \\
\hline Effort & 2.92 & 1.322 & -0.03 & -0.213 & $-0.309 *$ & 1 & & & & \\
\hline Risk & 2.74 & 1.322 & 0.119 & -0.373 & $-0.294 *$ & 0.210 & 1 & & & \\
\hline Fairness & 2.50 & 0.995 & 0.175 & -0.299 & $-0.402 *$ & 0.268 & $0.588 * * *$ & 1 & & \\
\hline Trustfulness & 2.46 & 1.034 & -0.148 & $-0.479 * * *$ & $-0.481 * *$ & $0.665^{* * *}$ & $0.419^{*}$ & $0.296^{*}$ & 1 & \\
\hline Friendliness & 2.04 & 1.009 & 0.054 & $-0.569 * * *$ & $-0.486 * *$ & 0.384 & $0.431 *$ & $0.5 * * *$ & $0.482 * * *$ & 1 \\
\hline
\end{tabular}

Table 9. Means, standard deviations and correlations of the motivators.

\begin{tabular}{lllllll}
\hline & Mean & S.D. & 1 & 2 & 3 & 4 \\
\hline Cope with resposibility & 3.00 & 1.738 & 1 & & & \\
Cope with obligation & 2.92 & 1.794 & $0.799 * * *$ & 1 & & \\
Gift exchange & 2.02 & 1.518 & $0.513 * * *$ & $0.594 * * *$ & 1 & \\
Use opportunity & 3.64 & 1.711 & $0.620^{* * *}$ & $0.603 * * *$ & $0.26 *$ & 1 \\
\hline Notes: $* \mathrm{p}<0.05, * * \mathrm{p}<0.01, * * * \mathrm{p}<0.001$ & & & & &
\end{tabular}

Table 10: Agent's responsibility and goal attainment.

\begin{tabular}{|c|c|c|c|c|}
\hline \multirow[b]{2}{*}{ Exog. Variable } & \multicolumn{2}{|c|}{ Responsibility } & \multicolumn{2}{|l|}{ Goal } \\
\hline & $\begin{array}{l}\text { Coefficient } \\
\text { (rse) }\end{array}$ & $\mathrm{P}>|\mathrm{t}|$ & $\begin{array}{l}\text { Coefficient } \\
\text { (rse) }\end{array}$ & $\mathrm{P}>|\mathrm{t}|$ \\
\hline $\begin{array}{l}\text { Cope with } \\
\text { resposibility }\end{array}$ & 0.344 & 0.045 & 0.165 & 0.148 \\
\hline Cope with obligation & -0.244 & 0.167 & 0.201 & 0.151 \\
\hline Gift exchange & 0.387 & 0.007 & -0.046 & 0.594 \\
\hline Use opportunity & 0.230 & 0.075 & 0.147 & 0.140 \\
\hline
\end{tabular}

Note: See Table 4.3. 
Table 11. Different framing. Responsibility.

\begin{tabular}{|c|c|c|c|c|}
\hline & \multicolumn{2}{|c|}{ Mean Session 1} & \multicolumn{2}{|c|}{ Mean Session 2-4 } \\
\hline & Agents & Principals & Agents & Principals \\
\hline Searchintensity & 53.3 & 51.7 & 52.1 & 51.5 \\
\hline Responsibility & 2.33 & 2.73 & 2.16 & 2.72 \\
\hline Goal & 5.2 & 5.07 & 4.74 & 4.86 \\
\hline Gift & 2.53 & 3 & 2.9 & 3.2 \\
\hline Giftbelief & 3.13 & 3.2 & 3.36 & 3.14 \\
\hline Desirability Del. & 1.67 & 2.6 & 2.5 & 3.22 \\
\hline Desirability Centr. & 4.67 & 3.47 & 3.58 & 3.22 \\
\hline
\end{tabular}

Note: The shown searchintensities of the principals are taken from the centralization treatment and for the agents from the delegation treatment.

Table 12. Reverse order. Impatience.

\begin{tabular}{|c|c|c|c|c|}
\hline \multirow[b]{3}{*}{ Searchintensity } & \multicolumn{2}{|c|}{ Mean Session 4} & \multicolumn{2}{|c|}{ Mean Session 2-3 } \\
\hline & Agents & Principals & Agents & Principals \\
\hline & 63.44 & 48.75 & 52.1 & 51.5 \\
\hline Responsibility & 1.81 & 2.13 & 2.16 & 2.72 \\
\hline Goal & 4.56 & 5.06 & 4.74 & 4.86 \\
\hline Gift & 3.13 & 3.63 & 2.9 & 3.2 \\
\hline Giftbelief & 3.31 & 3.31 & 3.36 & 3.14 \\
\hline Desirability Del. & 2.44 & 3.75 & 2.5 & 3.22 \\
\hline Desirability Centr. & 3.63 & 2.94 & 3.58 & 3.22 \\
\hline
\end{tabular}

Note: See Table 11.

Table 13. Role influence on the searchintensity in Session 4.

\begin{tabular}{l|lll}
\hline Exog. Variable & $\begin{array}{l}\text { Coefficient } \\
\text { (rse) }\end{array}$ & t-value & $\mathrm{P}>|\mathrm{t}|$ \\
\hline Goal & $8.479(2.06)$ & 4.11 & 0.000 \\
Principal & $-14.158(6.55)$ & -2.16 & 0.039 \\
\hline
\end{tabular}

Note: See Table 3. 


\section{Figures}

Figure 1. Expected utility of principal in the centralization treatment.

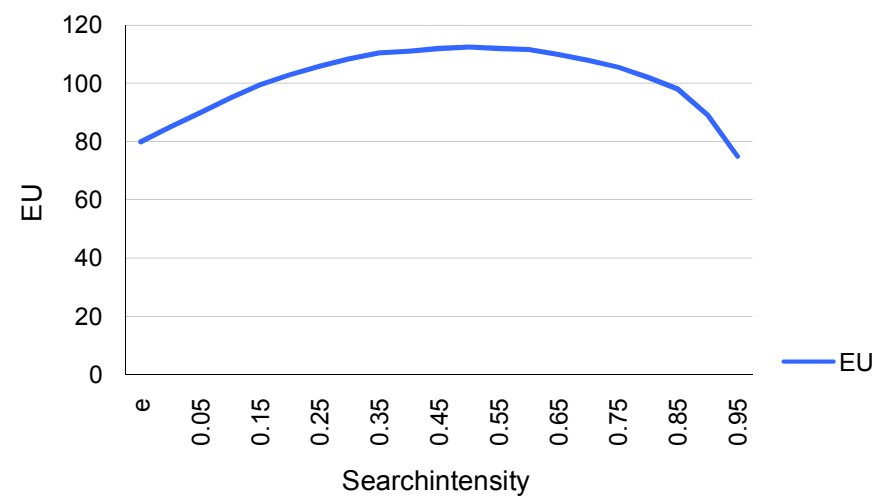

Figure 2. Expected utility under authority and delegation.

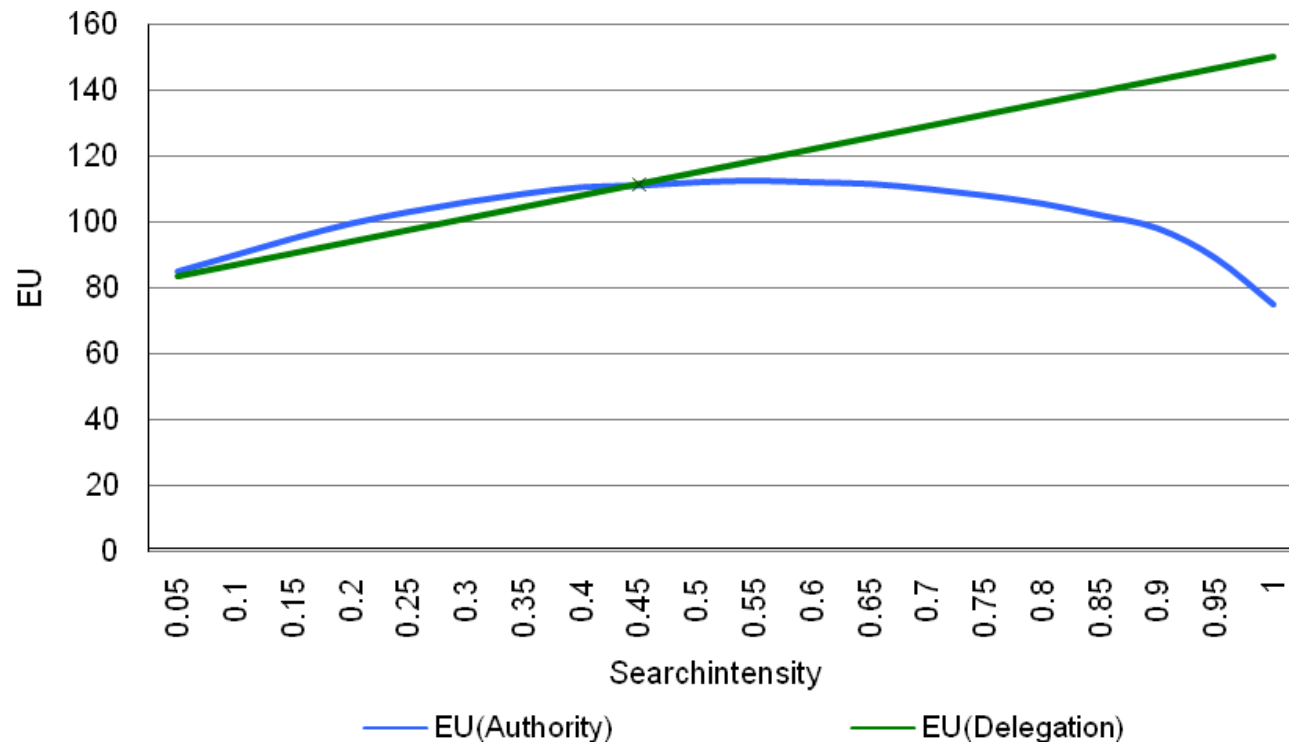


Figure 3. Principals' searchintensities in centralization treatment.

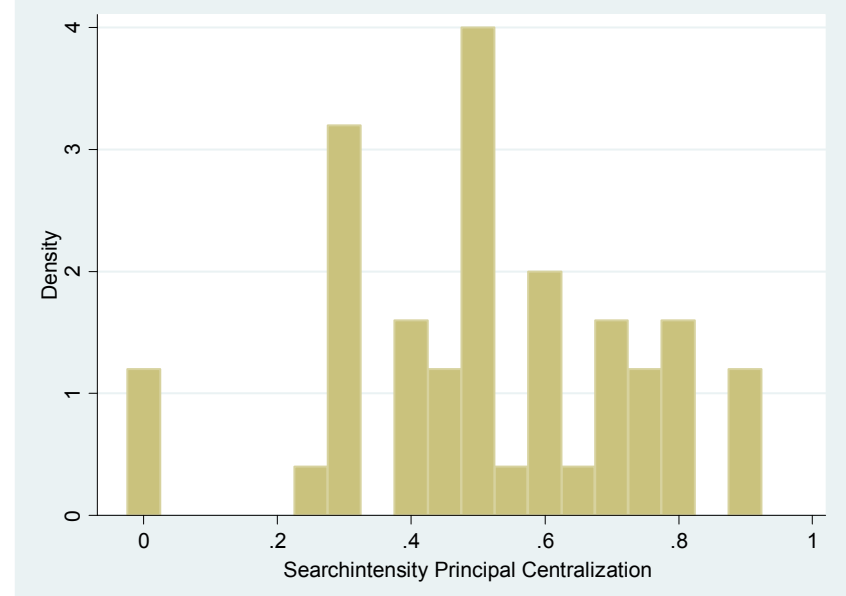

Figure 4. Principals' searchintensities in delegation treatment.

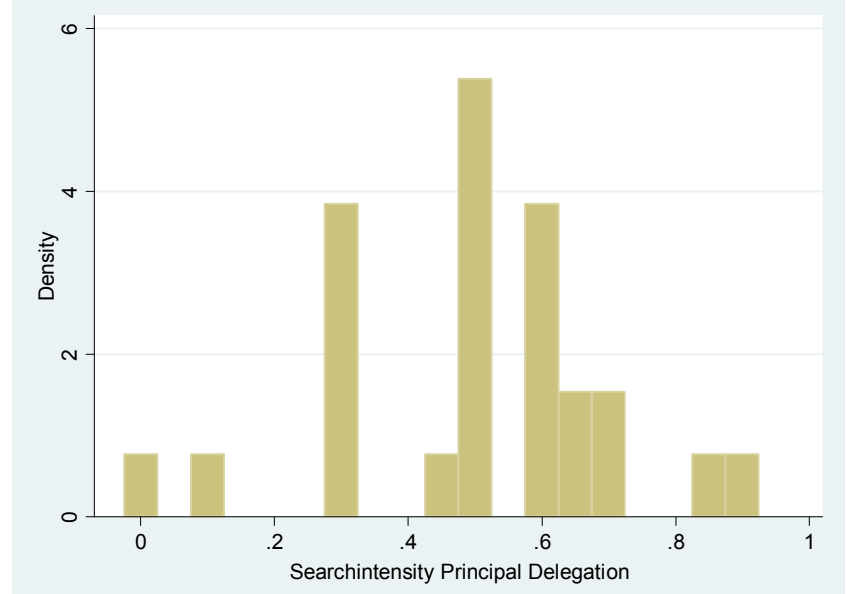

Figure 5. Agents' searchintensities in delegation treatment.

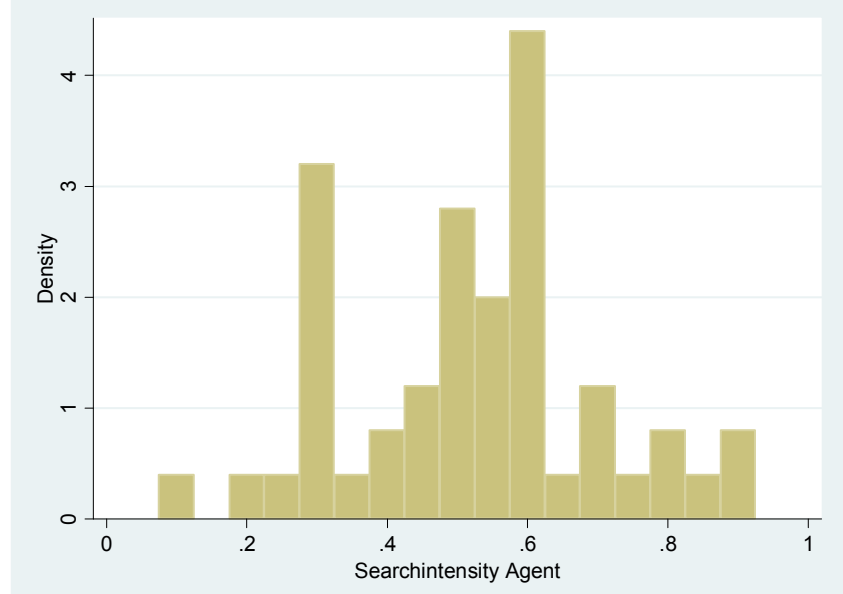


Figure 6. The differences between delegating and non-delegating principals.

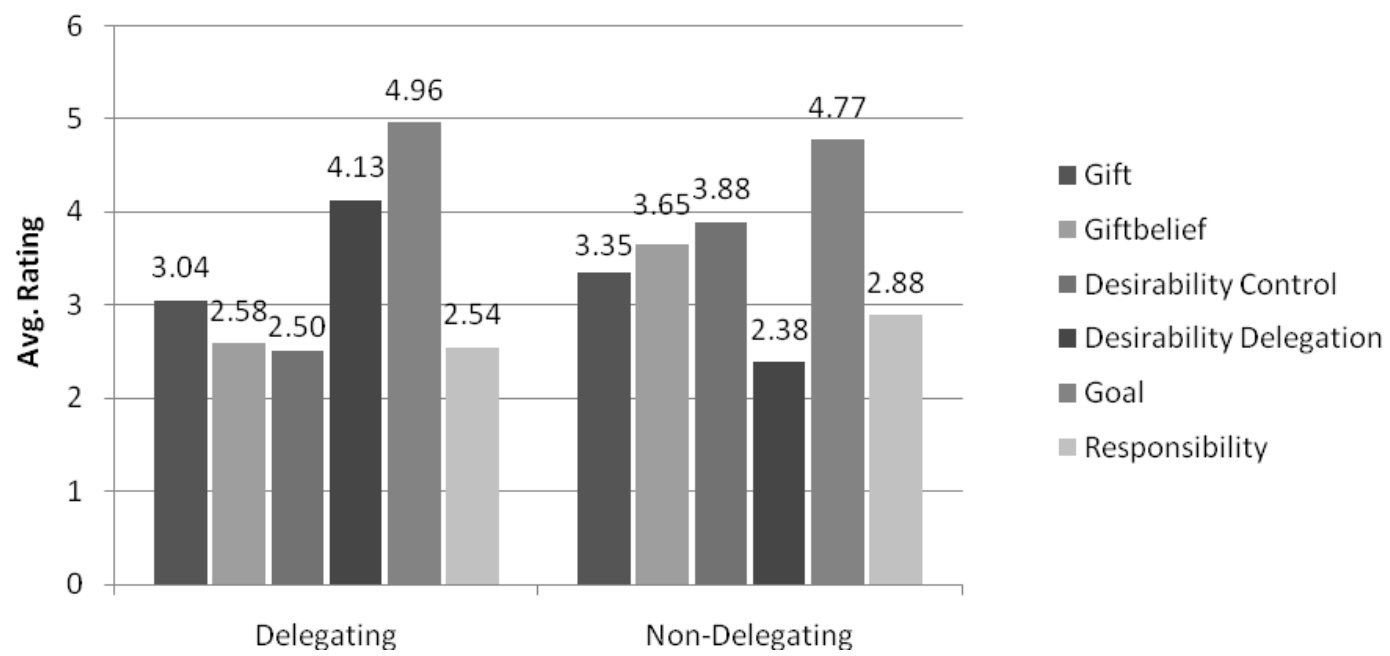

Figure 7. Agent's desirabilities and gift perceptions.

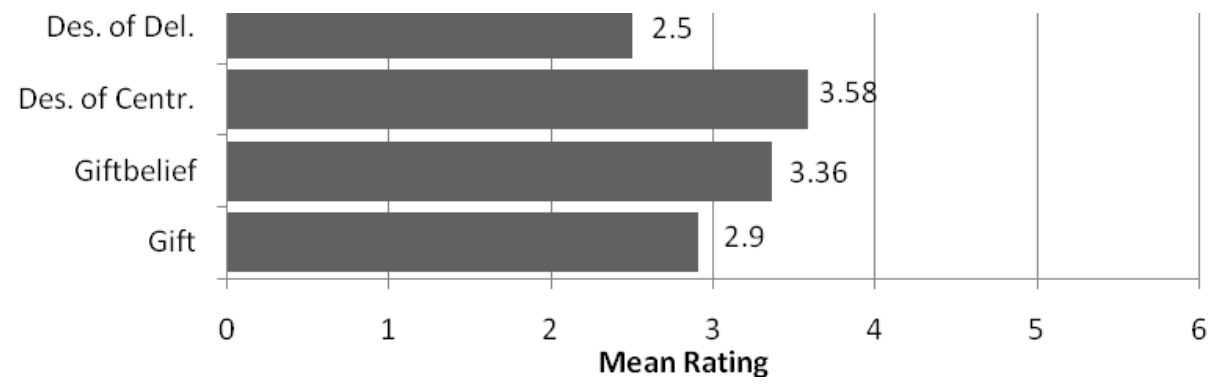

Figure 8. Means of the motivators amongst motivated agents.

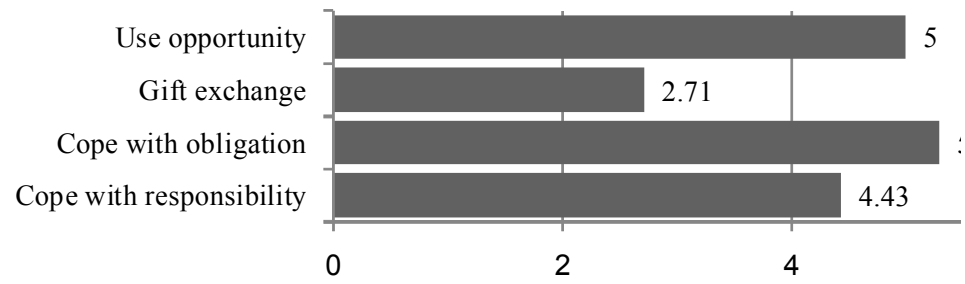


Figure 9. Net of interactions of motivators, responsibility and goal.

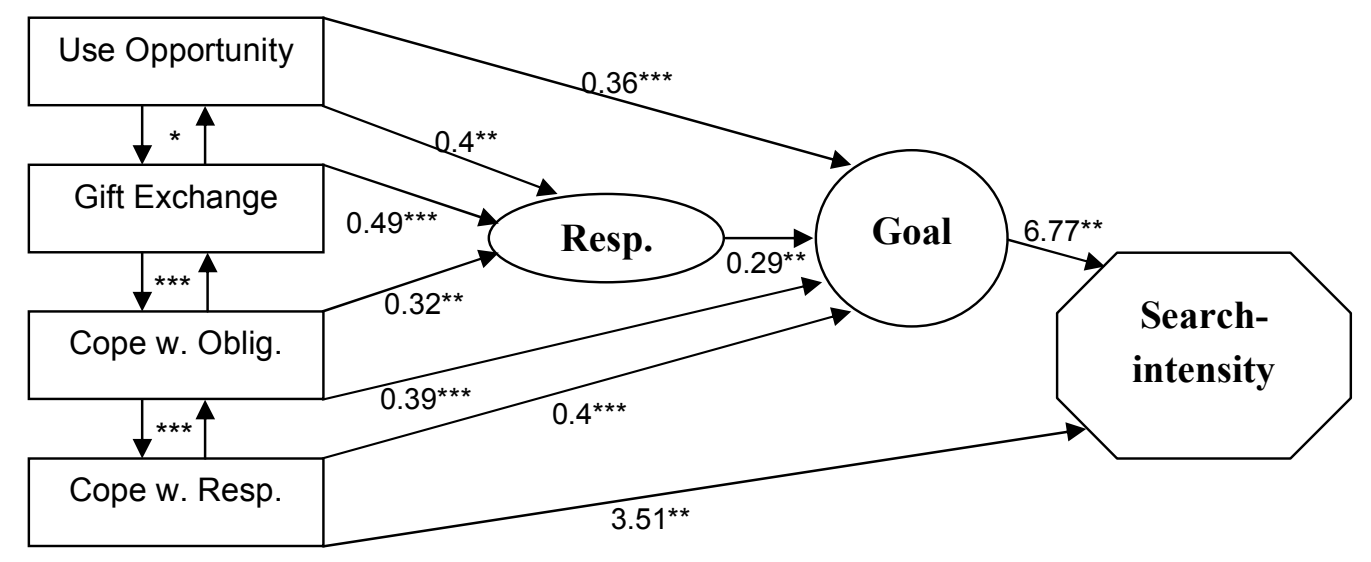

Notes: ${ }^{*} \mathrm{p}<0.05,{ }^{*} \mathrm{p}<0.01,{ }^{* * *} \mathrm{p}<0.001$

Figure 10. Net of interactions including delegation motives.

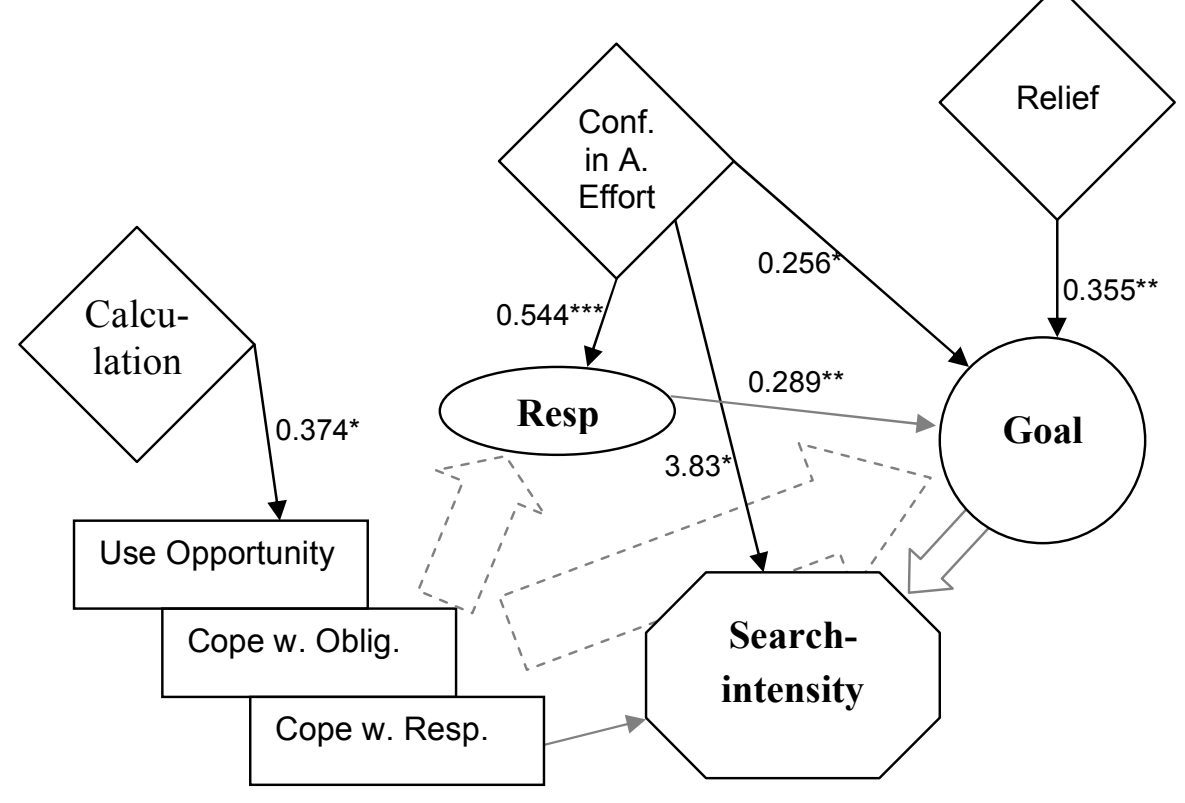

Notes: ${ }^{*} \mathrm{p}<0.09, * * \mathrm{p}<0.02, * * * \mathrm{p}<0.001$ 


\section{Appendix}

Appendix 1. Presentation of the variables.

The central depending variable is the Searchintensity chosen by the agents and principals in both treatments. For all the search intensities and beliefs about search intensities there was given a scale from zero to one hundred, at selectable intervals of five percent, corresponding to the percentage chance of a successful search. The search intensities are called $S A$ (for Agent's search intensity), $S P_{-}$Del (for Principal's search intensity in delegation Treatment), and SP_Centr (for Principal's search intensity in centralization).

An important group of variables represents the beliefs of the agents and the principals. In the delegation treatment the strategy method was used to elicit data of both parties, whether a delegation took place or not:

BA_Centr (for Belief Agent Centralization treatment) represents the estimation of an agent about the search intensity chosen by the principal in the centralization treatment.

BA_NoDel represents the estimation of an agent about the search intensity chosen by the principal in the delegation treatment in case of no delegation.

BA_Secorder was determined by the agents in the delegation treatment. The according question was: Which search intensity was expected of you by the principal (Participant A) if he delegated?

BP_Del stands for the principal's estimation in the delegation treatment about the search intensity chosen by the agent in case of delegation.

Another group of variables was gained through questioning the agents about their assumptions of the principal's (Participant A's) delegation motives. Each of the eight motives could be rated from one to five, in which a five stands for the strongest and a one for the weakest consent to a motive. The motives were given as follows (for the exact wording in German see Appendix 2).

Motive1 (Relief): The principal (Participant A) transferred the decision because he wants to relieve himself of the task.

Motive2 (Trustfulness): The principal delegated because he is trustful.

Motive3 (Calculation): The delegation took place because the principal is calculating. 
Motive4 (Confidence in Agent's Effort): The principal delegated out of confidence in the effort provided by me.

Motive5 (Risk): The principal is risk-loving and therefore transferred the decision rights.

Motive6 (Friendliness): The principal delegated out of friendliness.

Motive7 (Selfishness): The principal delegated out of selfishness.

Motive8 (Fairness): The principal delegated out of fairness.

To get more information about the agent's motivators in determining his search intensity, the following four variables were added. They could be rated from zero to six, whereas a six represents full and zero no accordance to the statement:

Cope with Responsibility: If I get the decision right I will choose a high searchintesity in order to cope with the responsibility.

Cope with Obligation: If I get the decision right I feel in a way obliged to choose a high search effort.

Gift Exchange: I regard the transfer of the decision right as a friendly act which I want to reciprocate by choosing a high serachintensity.

Use Opportunity: If I get the decision right I get the opportunity to choose my favourable card, that's why I choose a high search intensity.

In order to account for the gift exchange effect (e.g. Fehr \& Schmidt, 2000), which should be excluded in this experiment, the variables Gift and Giftbelief were added:

Gift represents the perceived friendliness of a delegation decision, rated from zero (= not friendly at all) to six (= very friendly).

Giftbelief represents the beliefs about the perceived friendliness of a delegation by the respective counterparties. The associated question was: How friendly is a delegation decision considered by the other party?

To examine the general sense of responsibility perceived by all agents and principals the variable called Responsibility was introduced. It represents the felt responsibility for the payoff of the counterparty and was rated analogously from zero (= not responsible at all) to six (= very responsible). 
The variable Goal stands for the degree of goal attainment and represents the rated importance of finding a good project/card from zero (=not important at all) to six (=very important).

Desirability Centralization (abbr.: Des. Centr.) represents the rated desirability from zero (=not desirable at all) to six (=very desirable) of no delegation in the delegation treatment.

Desirability Delegation (abbr.: Des. Del.) analogously represents the rated desirability of delegation of principals and agents. 
Appendix 2. Instructions Participant B (Agent). Delegation Treatment.

Wir begrüssen Sie ganz herzlich zu diesem wirtschaftswissenschaftlichen Experiment.

Sie nehmen nun an einer wissenschaftlichen Studie teil, die von diversen Forschungsförderungsstellen finanziert wird. Bitte lesen Sie die nachstehenden Ausführungen gewissenhaft durch. Hier wird Ihnen alles mitgeteilt, was Sie für die Teilnahme an der Studie wissen müssen. Falls Sie etwas nicht verstehen, melden Sie sich bitte. Ihre Frage wird dann an Ihrem Platz beantwortet.

Zu Beginn der Studie erhalten Sie ein Startgeld von 10 Franken. Im Verlauf der Studie können Sie einen weiteren Geldbetrag verdienen, indem Sie Punkte erzielen. Die Anzahl der Punkte, die Sie im Verlauf der Studie erzielen, hängt von Ihren Entscheidungen und den Entscheidungen anderer Teilnehmer ab.

Alle Punkte, die Sie in der Studie verdienen, werden am Schluss in Franken umgerechnet. Hierbei gilt, dass:

\section{Punkte $=1$ Franken}

Am Ende der Studie erhalten Sie den Geldbetrag, den Sie im Verlauf der Studie verdient haben plus die 10 Franken Startgeld in bar ausbezahlt.

Beachten Sie bitte, dass während der gesamten Studie ein striktes Kommunikationsverbot besteht. Zudem weisen wir Sie darauf hin, dass Sie am Computer nur diejenigen Funktionen bedienen dürfen, die für den Ablauf der Studie bestimmt sind. Kommunikation oder Herumspielen am Computer führen zum Ausschluss von der Studie. Bei Fragen stehen wir Ihnen gerne zur Verfügung.

Die heutige Sitzung besteht aus zwei Experimenten, die unabhängig voneinander sind. Diese Instruktionen beziehen sich auf das erste Experiment. Am Ende des ersten Experimentes werden Ihnen weitere Instruktionen zum zweiten Experiment ausgehändigt. Nach dem zweiten Experiment ist die Sitzung zu Ende und Sie erhalten Ihre Auszahlungen.

\section{Erstes Experiment der heutigen Studie}

In diesem Experiment gibt zwei Arten von Teilnehmern: Teilnehmer A und Teilnehmer B. Sie sind ein Teilnehmer B.

Sie werden zufällig und anonym einem anderen Teilnehmer A zugeordnet. Niemand wird erfahren, wer wem in diesem Experiment zugeordnet war.

Entweder Sie oder Teilnehmer $A$ haben in diesem Experiment das Entscheidungsrecht über die Wahl einer Karte. Ihre Auszahlung und die Auszahlung von Teilnehmer A hängen von der gewählten Karte ab. Es gibt insgesamt 35 Karten. Nur drei dieser Karten haben positive Auszahlungen für Sie und Teilnehmer A zur Folge. Alle Karten werden zu Beginn des Experiments gemischt und an einer zufälligen Position verdeckt ausgelegt. Lediglich eine Karte ist für Sie und Teilnehmer A sichtbar, die Grüne Karte. Es gibt zwei weitere Karten mit positiven Auszahlungen, 
die verdeckt ausliegen: Eine Rote Karte und eine Blaue Karte. Alle übrigen Karten sind Nieten mit einer Auszahlung von 0.

\section{Aufbau}

Der unten abgebildete Bildschirm zeigt Innen die Ausgangssituation der Karten. 35 Karten werden gemischt und zufällig an einer Position ausgelegt. Lediglich die Grüne Karte ist immer an Position 18:

\begin{tabular}{|c|c|c|c|c|c|c|}
\hline $\begin{array}{c}\text { Position } 1 \\
?\end{array}$ & $\begin{array}{c}\text { Position } 2 \\
?\end{array}$ & $\begin{array}{c}\text { Position } 3 \\
?\end{array}$ & $\begin{array}{c}\text { Position } 4 \\
?\end{array}$ & $\begin{array}{c}\text { Position } 5 \\
?\end{array}$ & $\begin{array}{c}\text { Position } 6 \\
?\end{array}$ & $\begin{array}{c}\text { Position } 7 \\
?\end{array}$ \\
\hline $\begin{array}{c}\text { Position } 8 \\
?\end{array}$ & $\begin{array}{c}\text { Position } 9 \\
?\end{array}$ & $\begin{array}{c}\text { Position } 10 \\
?\end{array}$ & $\begin{array}{c}\text { Position } 11 \\
?\end{array}$ & $\begin{array}{c}\text { Position } 12 \\
?\end{array}$ & $\begin{array}{c}\text { Position } 13 \\
?\end{array}$ & $\begin{array}{c}\text { Position } 14 \\
?\end{array}$ \\
\hline $\begin{array}{c}\text { Position } 15 \\
?\end{array}$ & $\begin{array}{c}\text { Position } 16 \\
?\end{array}$ & $\begin{array}{c}\text { Position } 17 \\
?\end{array}$ & $\begin{array}{l}\text { Position } 18 \\
\text { GRÜNE } \\
\text { KARTE }\end{array}$ & $\begin{array}{c}\text { Position } 19 \\
?\end{array}$ & $\begin{array}{c}\text { Position } 20 \\
?\end{array}$ & $\begin{array}{c}\text { Position } 21 \\
?\end{array}$ \\
\hline $\begin{array}{c}\text { Position } 22 \\
?\end{array}$ & $\begin{array}{c}\text { Position } 23 \\
?\end{array}$ & $\begin{array}{c}\text { Position } 24 \\
?\end{array}$ & $\begin{array}{c}\text { Position } 25 \\
?\end{array}$ & $\begin{array}{c}\text { Position } 26 \\
?\end{array}$ & $\begin{array}{c}\text { Position } 27 \\
?\end{array}$ & $\begin{array}{c}\text { Position } 28 \\
?\end{array}$ \\
\hline $\begin{array}{c}\text { Position } 29 \\
?\end{array}$ & $\begin{array}{c}\text { Position } 30 \\
?\end{array}$ & $\begin{array}{c}\text { Position } 31 \\
?\end{array}$ & $\begin{array}{c}\text { Position } 32 \\
?\end{array}$ & $\begin{array}{c}\text { Position } 33 \\
?\end{array}$ & $\begin{array}{c}\text { Position } 34 \\
?\end{array}$ & $\begin{array}{c}\text { Position } 35 \\
?\end{array}$ \\
\hline
\end{tabular}

\section{Die Karten}

Neben der Grünen Karte, deren Position beiden Teilnehmern bekannt ist, gibt es ausserdem die Rote Karte, die Blaue Karte und 32 Nieten. Diese liegen verdeckt an einer zufälligen Position. Jede Karte hat die in der unten stehenden Tabelle angegebenen Auszahlungen für Sie und Teilnehmer A zur Folge:

\begin{tabular}{|c|c|c|}
\hline Karte & Auszahlung Teilnehmer A & Ihre Auszahlung \\
\hline Blau & 150 & 200 \\
\hline Rot & 200 & 150 \\
\hline Grün & 80 & 80 \\
\hline Niete & 0 & 0 \\
\hline
\end{tabular}

\section{Detaillierter Ablauf}

In diesem Experiment haben entweder Sie oder Teilnehmer A das Entscheidungsrecht, nach der Roten und der Blauen Karte zu suchen und danach eine Kartenposition auszuwählen. Nur der Teilnehmer mit Entscheidungsrecht kann diese beiden 
Aktivitäten durchführen. Die gewählte Karte bestimmt dann die Auszahlungen sowohl für Sie als auch für Teilnehmer $A$.

\section{Stufe: Wer hat das Entscheidungsrecht?}

Am Anfang hat zunächst Teilnehmer A das Entscheidungsrecht. Dieser kann

- das Entscheidungsrecht behalten.

- das Entscheidungsrecht an Sie übertragen.

\section{Stufe: Die Suche nach Karten}

Nur der Teilnehmer mit Entscheidungsrecht kann nach der Roten und der Blauen Karte suchen.

Wenn Teilnehmer A Ihnen das Entscheidungsrecht übertragen hat, dann können Sie nach der Position der Blauen und der Roten Karte suchen und anschliessend eine Karte auswählen. Wenn Teilnehmer A das Entscheidungsrecht behalten hat, dann kann er nach den Karten suchen und anschliessend eine Kartenposition auswählen.

Wenn die Suche erfolgreich ist, dann werden alle Karten gedreht und die Positionen der Roten und der Blauen Karte werden bekannt. Sollte die Suche ohne Erfolg sein, so ist nach wie vor nur die Position der Grünen Karte bekannt und alle anderen Karten bleiben verdeckt.

\section{Wie wird gesucht?}

Der Teilnehmer, der das Entscheidungsrecht innehat, bestimmt eine Suchintensität zwischen 0 und 100. Die Suchintensität entspricht genau der Wahrscheinlichkeit, mit der ALLE Karten aufgedeckt werden.

$\mathbf{0} \leq$ Suchintensität $\leq \mathbf{1 0 0}$

Eine Suchintensität von 0 bedeutet also, dass die Karten NIE aufgedeckt werden. Eine Suchintensität von 100 bedeutet, dass die Karten IMMER aufgedeckt werden. Für alle Werte dazwischen kann es vorkommen, dass die Karten aufgedeckt werden oder nicht.

\section{Die Kosten der Suche}

Je höher die Suchintensität, die gewählt wird, desto höher sind die Kosten. Die Suchkosten für Teilnehmer A sind identisch zu Ihren. Die folgende Tabelle zeigt Ihnen die Kosten zu jeder möglichen Suchintensität an. Es sind nur Suchintensitäten in 5er Schritten wählbar:

\begin{tabular}{|l|c|c|c|c|c|c|c|c|c|c|c|}
\hline Suchintensität & 0 & 5 & 10 & 15 & 20 & 25 & 30 & 35 & 40 & 45 & 50 \\
\hline Kosten in Punkten & 0 & 1 & 2 & 3 & 4.5 & 7 & 10 & 13.5 & 17.5 & 23 & 28 \\
\hline
\end{tabular}




\begin{tabular}{|l|c|c|c|c|c|c|c|c|c|c|}
\hline Suchintensität & 55 & 60 & 65 & 70 & 75 & 80 & 85 & 90 & 95 & 100 \\
\hline Kosten in Punkten & 33.5 & 40 & 46.5 & 54 & 62 & 70.5 & 80 & 90 & 105 & 125 \\
\hline
\end{tabular}

Bitte beachten Sie stets diese Tabelle, wenn Sie Ihre Suchintensität wählen.

Dabei gilt stets:

Je höher die Suchintensität, die gewählt wird, desto wahrscheinlicher ist es, dass die Karten aufgedeckt werden und die Positionen der Roten und der Blauen Karte bekannt werden. Allerdings sind auch die Kosten umso höher, je höher die Suchintensität gewählt wird.

\section{Der Erfolg der Suche}

Der Computer bestimmt dann mit Hilfe der gewählten Suchintensität, ob die Karten aufgedeckt werden. Dies können Sie sich folgendermassen vorstellen:

Die gewählte Suchintensität liegt zwischen 0 und 100. Der Computer zieht nun zufällig eine von 100 Kugeln, die von 1 bis 100 numeriert sind. Ist diese gezogene Zahl kleiner oder gleich der gewählten Suchintensität, so werden alle Karten aufgedeckt. Ist sie jedoch grösser als die gewählte Suchintensität, so werden die Karten nicht aufgedeckt. Somit entspricht die Suchintensität exakt der Wahrscheinlichkeit, mit der die Karten gedreht werden.

Beispiele:

1. Es wird eine Suchintensität von 15 gewählt:

Wenn zufällig eine Kugel mit einer Zahl zwischen 1 und 15 (=15 von 100 Kugeln) gezogen wird, werden alle Karten aufgedeckt. Ist die Zahl grösser als 15 (16-100; also 85 von 100 Kugeln), werden die Karten nicht aufgedeckt.

2. Es wird eine Suchintensität von 75 gewählt:

Wenn zufällig eine Kugel mit einer Zahl zwischen 1 und 75 (= 75 von 100 Kugeln) gezogen wird, werden alle Karten aufgedeckt. Ist die Zahl grösser als 75 (76-100; also 25 von 100 Kugeln), werden die Karten nicht aufgedeckt. 
Wenn die Suche erfolgreich war, werden alle Karten aufgedeckt und die Position der Roten und der Blauen Karte werden aufgedeckt. Sie sehen dann folgenden Bildschirm (Beispiel):

\begin{tabular}{|c|c|c|c|c|c|c|}
\hline $\begin{array}{c}\text { Position } 1 \\
0\end{array}$ & $\begin{array}{c}\text { Position } 2 \\
0\end{array}$ & $\begin{array}{c}\text { Position } 3 \\
0\end{array}$ & $\begin{array}{c}\text { Position } 4 \\
0\end{array}$ & $\begin{array}{c}\text { Position } 5 \\
0\end{array}$ & $\begin{array}{c}\text { Position } 6 \\
0\end{array}$ & $\begin{array}{c}\text { Position } 7 \\
0\end{array}$ \\
\hline $\begin{array}{c}\text { Position } 8 \\
0\end{array}$ & $\begin{array}{l}\text { Position } 9 \\
\text { ROTE } \\
\text { KARTE }\end{array}$ & $\begin{array}{c}\text { Position } 10 \\
0\end{array}$ & $\begin{array}{c}\text { Position } 11 \\
0\end{array}$ & $\begin{array}{c}\text { Position } 12 \\
0\end{array}$ & $\begin{array}{c}\text { Position } 13 \\
0\end{array}$ & $\begin{array}{c}\text { Position } 14 \\
0\end{array}$ \\
\hline $\begin{array}{c}\text { Position } 15 \\
0\end{array}$ & $\begin{array}{c}\text { Position } 16 \\
0\end{array}$ & $\begin{array}{c}\text { Position } 17 \\
0\end{array}$ & $\begin{array}{l}\text { Position } 18 \\
\text { GRÜNE } \\
\text { KARTE }\end{array}$ & $\begin{array}{c}\text { Position } 19 \\
0\end{array}$ & $\begin{array}{c}\text { Position } 20 \\
0\end{array}$ & $\begin{array}{c}\text { Position } 21 \\
0\end{array}$ \\
\hline $\begin{array}{c}\text { Position } 22 \\
0\end{array}$ & $\begin{array}{c}\text { Position } 23 \\
0\end{array}$ & $\begin{array}{c}\text { Position } 24 \\
0\end{array}$ & $\begin{array}{c}\text { Position } 25 \\
0\end{array}$ & $\begin{array}{c}\text { Position } 26 \\
0\end{array}$ & $\begin{array}{c}\text { Position } 27 \\
0\end{array}$ & $\begin{array}{c}\text { Position } 28 \\
0\end{array}$ \\
\hline $\begin{array}{l}\text { Position } 29 \\
\text { BLAUE } \\
\text { KARTE }\end{array}$ & $\begin{array}{c}\text { Position } 30 \\
0\end{array}$ & $\begin{array}{c}\text { Position } 31 \\
0\end{array}$ & $\begin{array}{c}\text { Position } 32 \\
0\end{array}$ & $\begin{array}{c}\text { Position } 33 \\
0\end{array}$ & $\begin{array}{c}\text { Position } 34 \\
0\end{array}$ & $\begin{array}{c}\text { Position } 35 \\
0\end{array}$ \\
\hline
\end{tabular}

\section{Stufe: Die Kartenwahl}

Nachdem der Teilnehmer mit Entscheidungsrecht nach der Roten und der Blauen Karte gesucht hat, entscheidet er allein, welche Kartenposition ausgewählt wird. Falls die Suche erfolgreich war, kennt er hierbei die Positionen der Roten und der Blauen Karte. Falls die Suche nicht erfolgreich war, ist nur die Position der grünen Karte bekannt.

\section{Die Einkommen}

1. Falls Teilnehmer A Ihnen das Entscheidungsrecht übertragen hat, setzt sich Ihr Einkommen aus den folgenden beiden Bestandteilen zusammen:

- dem Einkommen aus der von Ihnen gewählten Karte

- abzüglich der Kosten der Suche

Einkommen $=$ Einkommen aus der von Ihnen gewählten Karte - Suchkosten

2. Falls Teilnehmer $\mathbf{A}$ das Entscheidungsrecht behalten hat, fallen für Sie keine Suchkosten an und Ihr Einkommen wird einzig durch die Kartenwahl von Teilnehmer A bestimmt. 


\section{Einkommen = Einkommen aus der von Teilnehmer A gewählten Karte}

\section{Zusammenfassung des Ablaufs des ersten Experiments}

1) $\mathrm{Zu}$ Beginn entscheidet Teilnehmer $\mathrm{A}$, ob er das Entscheidungsrecht an Sie übertragen oder behalten möchte.

2) Daraufhin kann der Teilnehmer, der das Entscheidungsrecht innehat, versuchen die Position der Roten und der Blauen Karte herauszufinden.

3) Der Teilnehmer mit Entscheidungsrecht erfährt gemäss der von Ihm gewählten Suchintensität die Positionen der Karten. Daraufhin kann er eine Karte auswählen, und die damit verbundenen Auszahlungen werden realisiert.

\section{Ablauf am Computer}

\section{Stufe: Die Suche}

Zunächst trifft Teilnehmer A die Entscheidung, ob er das Entscheidungsrecht an Sie übertragen möchte oder nicht.

Wenn Sie Ihre Suchintensität wählen, wissen Sie noch nicht, ob Teilnehmer A das Entscheidungsrecht an Sie übertragen hat oder nicht. Sie wählen daher eine Suchintensität für den Fall, dass Teilnehmer A das Entscheidungsrecht an Sie überträgt. Je höher Sie diese Suchintensität wählen, umso wahrscheinlicher ist es, dass Sie die Positionen der Roten und der Blauen Karte erfahren. Allerdings sind Ihre Kosten auch umso höher, je höher Sie die Suchintensität wählen. Ihre Angaben werden allerdings nur dann relevant, wenn Teilnehmer A tatsächlich das Entscheidungsrecht an Sie überträgt. Ihre Entscheidung über die Suchintensität treffen Sie auf dem unten abgebildeten Bildschirm: 


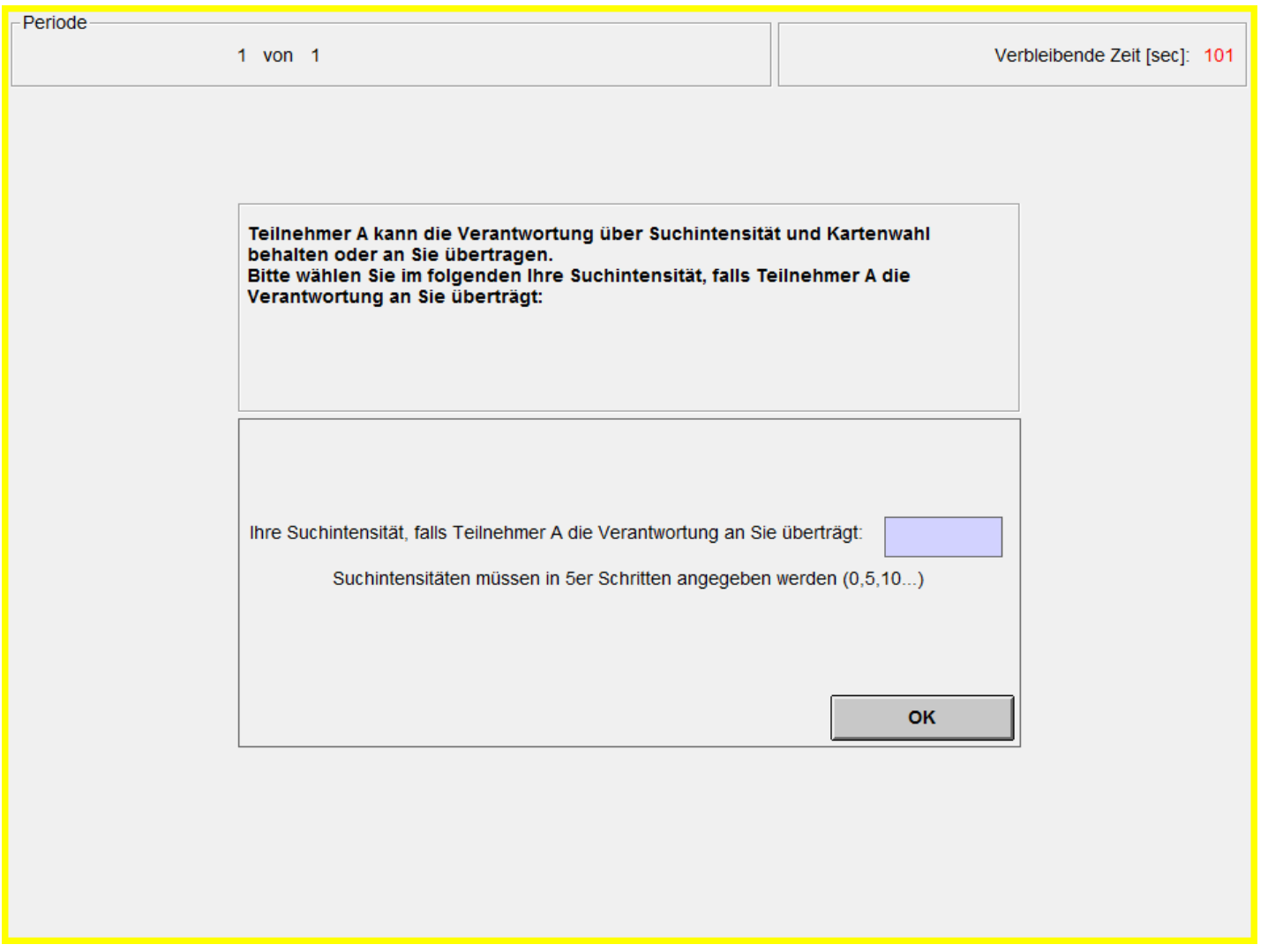

Nachdem Sie Ihre Suchintensität eingegeben haben, werden Ihnen diese Intensität und die damit verbundenen Kosten noch einmal angezeigt. Falls Sie Ihre Entscheidung noch einmal ändern möchten, klicken Sie auf „Suchintensität ändern“. Ansonsten klicken Sie OK.

\section{Stufe: Die Kartenwahl}

Falls Teilnehmer A das Entscheidungsrecht behalten hat, kann dessen Suche erfolgreich oder erfolglos verlaufen sein. Je nach Verlauf der Suche kennt daher Teilnehmer A die Positionen der Blauen und der Roten Karte (oder nicht) und kann anschliessend eine Karte auswählen.

Falls Teilnehmer A das Entscheidungsrecht an Sie übertragen hat, kann Ihre Suche ebenfalls erfolgreich oder erfolglos verlaufen sein.

In dieser Stufe wüssten wir gerne von Ihnen, welche Kartenposition Sie in diesem Fall (Ihnen wurde das Entscheidungsrecht übertragen) auswählen würden, je nachdem ob Ihre Suche erfolgreich war oder nicht. Zunächst sehen Sie den Kartenbildschirm mit verdeckten Kartenpositionen (ausser der grünen Karte). Bitte wählen Sie dort eine Kartenposition für den Fall aus, dass Ihre Suche erfolglos ist. 
Bitte treffen Sie hier Ihre Wahl für den Fall, dass Ihre Suche nicht erfolgreich gewesen sein sollte:

\begin{tabular}{|c|c|c|c|c|c|c|}
\hline $\begin{array}{c}\text { Position } 1 \\
?\end{array}$ & $\begin{array}{c}\text { Position } 2 \\
?\end{array}$ & $\begin{array}{c}\text { Position } 3 \\
?\end{array}$ & $\begin{array}{c}\text { Position } 4 \\
?\end{array}$ & $\begin{array}{c}\text { Position } 5 \\
\quad ?\end{array}$ & $\begin{array}{c}\text { Position } 6 \\
?\end{array}$ & $\begin{array}{c}\text { Position } 7 \\
?\end{array}$ \\
\hline $\begin{array}{c}\text { Position } 8 \\
?\end{array}$ & $\begin{array}{c}\text { Position } 9 \\
?\end{array}$ & $\begin{array}{c}\text { Position } 10 \\
?\end{array}$ & $\begin{array}{l}\text { Position } 11 \\
\qquad ?\end{array}$ & $\begin{array}{c}\text { Position } 12 \\
\text { ? }\end{array}$ & $\begin{array}{c}\text { Position } 13 \\
\text { ? }\end{array}$ & $\begin{array}{c}\text { Position } 14 \\
?\end{array}$ \\
\hline $\begin{array}{c}\text { Position } 15 \\
\text { ? }\end{array}$ & $\begin{array}{c}\text { Position } 16 \\
?\end{array}$ & $\begin{array}{c}\text { Position } 17 \\
?\end{array}$ & $\begin{array}{l}\text { Position } 18 \\
\text { GRÜNE } \\
\text { KARTE }\end{array}$ & $\begin{array}{c}\text { Position } 19 \\
\text { ? }\end{array}$ & $\begin{array}{c}\text { Position } 20 \\
?\end{array}$ & $\begin{array}{c}\text { Position } 21 \\
?\end{array}$ \\
\hline $\begin{array}{c}\text { Position } 22 \\
?\end{array}$ & $\begin{array}{c}\text { Position } 23 \\
\text { ? }\end{array}$ & $\begin{array}{c}\text { Position } 24 \\
?\end{array}$ & $\begin{array}{c}\text { Position } 25 \\
?\end{array}$ & $\begin{array}{c}\text { Position } 26 \\
?\end{array}$ & $\begin{array}{c}\text { Position } 27 \\
?\end{array}$ & $\begin{array}{c}\text { Position } 28 \\
?\end{array}$ \\
\hline $\begin{array}{c}\text { Position } 29 \\
?\end{array}$ & $\begin{array}{c}\text { Position } 30 \\
?\end{array}$ & $\begin{array}{c}\text { Position } 31 \\
?\end{array}$ & $\begin{array}{c}\text { Position } 32 \\
?\end{array}$ & $\begin{array}{c}\text { Position } 33 \\
?\end{array}$ & $\begin{array}{c}\text { Position } 34 \\
?\end{array}$ & $\begin{array}{c}\text { Position } 35 \\
?\end{array}$ \\
\hline
\end{tabular}

Danach werden die Kartenpositionen aufgedeckt. Bitte geben Sie nun eine Kartenposition für den Fall an, dass Ihre Suche erfolgreich ist.

In beiden Fällen funktioniert die Kartenwahl folgendermassen:

Geben Sie bitte in das Feld „Welche Kartenposition möchten Sie auswählen“ die Kartenposition ein, die Sie auswählen möchten. Jede Position, inklusive der Position der Grünen Karte (Position 18) ist hierbei wählbar. Wenn Sie Ihre Auswahl getroffen haben, dann klicken Sie bitte OK und bestätigen Ihre Eingabe.

\section{Stufe: Ihr Einkommen}

Unabhängig davon ob Ihnen das Entscheidungsrecht übertragen wurde oder nicht, erfahren Sie erst am Ende der heutigen Sitzung, ob Ihre Suche oder - falls Sie das Entscheidungsrecht nicht übertragen wurde - ob die Suche von Teilnehmer A erfolgreich war. Auch die gewählte Karte erfahren Sie erst am Ende der heutigen Sitzung. Sie erfahren also erst nach dem zweiten Experiment, wie hoch Ihr Einkommen aus diesem ersten Experiment ist.

Am Schluss der Sitzung wird die Summe der in beiden Experimenten verdienten Punkte in Franken umgerechnet. Diesen Betrag bekommen Sie zusammen mit dem fixen Geldbetrag für die Teilnahme an der Untersuchung in bar ausbezahlt. 
Sobald alle Teilnehmer Ihre Entscheidungen zum ersten Experiment getroffen haben werden wir Ihnen weitere Instruktionen zum zweiten Experiment aushändigen. Bitte lesen Sie sich diese wiederum gewissenhaft durch.

Bitte beantworten Sie die folgenden Kontrollfragen. Schreiben Sie den ganzen Rechenvorgang auf. Bei Fragen wenden Sie sich bitte an die Experimentatoren. Ihre Antworten haben keinen Einfluss auf Ihre Auszahlung am Ende der Sitzung sondern dienen der Kontrolle Ihres Verständnisses der Instruktionen.

1. Teilnehmer $A$ hat das Entscheidungsrecht nicht an Sie übertragen. Er hat eine Suchintensität von 10 gewählt. Die Suche hatte Erfolg. Er entscheidet sich die ROTE Karte auszuwählen.

Wie hoch ist Ihr Einkommen? ........

Wie hoch ist das Einkommen von Teilnehmer A? ........

2. Teilnehmer $A$ hat das Entscheidungsrecht nicht an Sie übertragen. Er hat eine Suchintensität von 10 gewählt. Die Suche hatte keinen Erfolg. Er entscheidet sich, Kartenposition 18 auszuwählen.

Wie hoch ist Ihr Einkommen?

Wie hoch ist das Einkommen von Teilnehmer A? ........

3. Teilnehmer $A$ hat das Entscheidungsrecht an Sie übertragen. Sie haben eine Suchintensität von 50 gewählt. Die Suche hatte Erfolg. Sie entscheiden sich, die BLAUE Karte auszuwählen.

Wie hoch ist Ihr Einkommen?

Wie hoch ist das Einkommen von Teilnehmer A? ........

4. Teilnehmer $A$ hat das Entscheidungsrecht an Sie übertragen. Sie hat eine Suchintensität von 50 gewählt. Die Suche hatte keinen Erfolg. Sie entscheiden sich, Kartenposition 18 auszuwählen.

Wie hoch ist Ihr Einkommen?

Wie hoch ist das Einkommen von Teilnehmer A?

5. Teilnehmer $A$ hat das Entscheidungsrecht nicht an Sie übertragen. Er hat eine Suchintensität von 90 gewählt. Die Suche hatte Erfolg. Er entscheidet sich die ROTE Karte auszuwählen.

Wie hoch ist Ihr Einkommen? ........

Wie hoch ist das Einkommen von Teilnehmer A? ........

6. Teilnehmer A hat das Entscheidungsrecht nicht an Sie übertragen. Er hat eine Suchintensität von 90 gewählt. Die Suche hatte keinen Erfolg. Er entscheidet sich, Kartenposition 18 auszuwählen.

Wie hoch ist Ihr Einkommen?

Wie hoch ist das Einkommen von Teilnehmer A? ....... 